シンポジウム|大血管

\title{
シンポジウム 01
}

\section{遺伝性結合組織疾患診察の最前線}

座長:湊谷 謙司(京都大学),川原田 修義(札幌医科大学)

2019年2月11日(月) 14:50 16:40 A会場 (岡山コンベンションセンター 3F コンベンションホール)

(2019年2月11日(月) 14:50～16:40 A会場)

[SY1-1] 遺伝性結合組織疾患の包括的診療 : 診断 ·治療 ·管理 ·遺伝カウン セリング

○森崎 裕子 (公益財団法人日本心臓血圧研究振興会附属 榊原記念病院 臨床遺伝科)

単一遺伝子の異常により発症する遺伝性大動脈疾患は、Marfan症候群や Ehlers-Danlos症候群など全身性結合組 織異常に合併する症候群性のものと、血管平滑筋などの大動脈構成成分の異常によって発症し、血管外症状を伴 わない非症候群性のものとに大別される。症候群性の場合、疾患特異的な身体所見から比較的早期に診断される 場合もあるが、一般的に血管症状の発現は他にくらべて遅れることが多いため、血管合併症の増悪が見逃される ことは少なくない。非症候群性大動脈疾患についても、大動脈解離などの重篤な合併症を発症する前の診断は従 来困難であった。しかし、近年の分子生物学的技術の進展により、これらの単一遺伝子疾患については、血液ゲ ノムの解析による遺伝学的診断が可能となり、早期診断・早期治療介入、さらには生命予後の改善へとつながる ことが期待されている。さらに、原因となる遺伝子の同定は、大動脈瘤・解離の分子生物学的発症機序の解明へ とつながり、疾患の病態にあわせた治療法の開発にもつながっている。他方、実臨床の場においては、遺伝学的 診断を考慮すべき症例の選別や検査のタイミング、診断が確定したのちの患者管理や心理支援、親族へのアプ ローチ、など、これまでとは異なる様々な問題も生じている。このセッションでは、こうした遺伝性結合組織疾 患の原因遺伝子別臨床像の特徵と治療・管理、遺伝カウンセリングなど、診断前から診断後にいたる包括的診療 体制について考察する。

(2019年2月11日(月) 14:50 16:40 A会場)

[SY1-2] 遺伝性結合織疾患診療の最前線：チーム医療の必要性

○荻野均 (東京医科大学 心臓血管外科)

2000年に国立循環器病研究センターでのキャリアを開始して以来、現在まで遺伝性結合織疾患（CTD）患者の外 科治療を多く担当してきた。この間、従来からの Marfan症候群に加え、Loyes-Dietz症候群、Ehlers-Danlos症候 群などの遺伝子診断が進み、その他の類縁疾患も明かになっていった。また、通常の大動脈解離の手術だけに留 まらず、CTD患者の多くが、解離、非解離に関わらず自己弁温存大動脈基部置換手術（VSRR）を必要とし、自 身の本術式確立の過程で重要な要因になった。自身の VSSRの70\%以上が何らかの CTD患者であり、自己弁の耐 久性を含めその遠隔成績は良好である。また、外科治療において議論の対象は、CTD患者に対するステントグラ フト治療の可否である。両方の意見があり、結論には至っていないが、オープンステントグラフトを含め慎重な 使用が望まれる。さらに、CTD患者の予後が解離発症有る無しで大きく異なることはいくつかの報告で明らかに なっている。解離発症前にいかにCTD患者を見つけ出し、解離を防止すべく予防的薬物治療やVSSRなどの外科 治療を、時期を含め、いかに適切に施行するかが重要となる。そのためには、CTD専門の特殊外来など、診 断、薬物治療の両面において遺伝性疾患を担当する小児科医や内科医を含めたチーム医療体制が、CTD患者の心 理的ケアを含め肝要と考える。 
(2019年2月11日(月) 14:50 16:40 A会場)

\section{[SY1-3] Marfan症候群と Loeys-Dietz症候群の遠隔期成績から見た今後のと るべき治療方針とは?}

○清家 愛幹, 松田 均, 井上大志, 四方 大地, 松尾二郎, 井上陽介, 大村 篤史, 上原京勲, 佐々木 啓明, 小林順二郎 (国 立循環器病研究センター)

【目的】Marfan症候群（MFS:FBN 1 遺伝子变異）及び Loeys-Dietz症候群（LDS：TGFBR1、TGFBR2、 SMAD3、TGFB2変異）の遺伝子診断がなされている若年の胸部大動脈手術症例について、遠隔期成績を比較検討 した。【対象と方法】対象は1998年1月から2018年4月までに大動脈外科治療を施行した手術時年齢50歳未満の 胸部大動脈手術症例351例のうち、FBN 1 遺伝子変異を有する MFS 97例（28\%）、及び TGFBR1、TGFBR2、 SMAD3、TGFB2の各遺伝子変異を有するLDS（類縁疾患を含む）27例（7.7\%）を対象とした。MFSは中央值 33歳、男/女 : 40/57、LDSは中央值28歳、男/女 : 15/10) で、男女比は同等（ $P=0.145 ） 、$ 年齢は LDSで有 意に若年であった $(P=0.005)$ 。観察期間は MFS/LDS：123/138力月 $(P=0.36)$ で同等であった。【結果】初診 時の診断は MFSでは A 型解離26例（急性23例、慢性3例）、慢性 B型解離15例、AAE 55例、腹部大動脈瘤破裂 1例、LDSでは A 型解離8例（急性5例、慢性3例）、慢性 B型解離8例、AAE 10例であり、MFSに AAEが多い傾

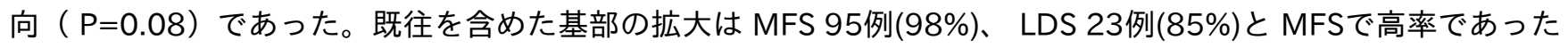

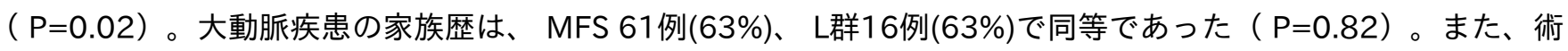
前高血圧症例も $M$ 群 19例(29\%)、L群10例(37\%)で同等であった（ $P=0.48 ） 。$ 病院死亡は両群ともに認め ず。遠隔期死亡は MFS 5例（大動脈破裂、心不全、脳出血、食中毒、自殺）、LDS1例（突然死）であった。累積 生存率(10/15年)は、MFS (98/91\%)：LDS(96/96\%)( $\mathrm{P}=0.50)$ と有意差は認めず。再手術回避率(10/15年)は MFS (48/22\%)：LDS(23/12\%)(P=0.02)と LDSで有意に低率であった。再解離回避率(10/15年)も MFS (83/69\%) : LDS(58/48\%)(P=0.015)と LDSで有意に低率であった。基部が手術適応になっていない症例は

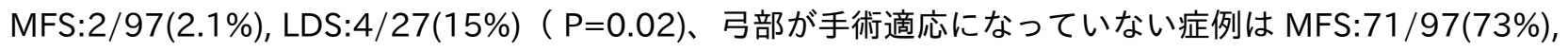
LDS:10/27(37\%)（P<0.001)であり、MFSでは弓部大動脈の拡大に対する手術適応が低率であった。【結 語】両群とも良好な手術成績の一方で、MFSに比較して LDSで有意に再手術及び再解離回避率が低率で あった。特にLDSでは早期・拡大手術などが重要であるが、MFSにおける弓部大動脈の拡大に対する手術適応は 低率で基部手術時の付加的弓部置換術の適応は慎重に考慮すべきであると思われた。

(2019年2月11日(月) 14:50 16:40 A会場)

\section{[SY1-4] 結合織疾患に対する大動脈基部置換術の外科治療成績}

飛永 覚, 床嶋 賢弘, 新谷悠介，財間 康之，税所 宏幸，福田 倫史，大塚 裕之，高木数実，高瀬谷徹，金本亮，有永康 一, 田中 啓之 (久留米大学病院外科)

目的)結合織疾患における大動脈基部病変に対しては解離発症前の積極的な基部置換が推奨されている。今回結合 識疾患における大動脈基部病変に対する外科治療成績を検討した。対象と方法）1990年 1 月から2018年8月に大 動脈基部置換術を施行した280例中、結合識疾患を有する症例33例(35手術)を対象とした。内訳は Marfan症候群 29例、Shprintzen-Goldberg 症候群2例、Loeys-Dietz症候群2例。平均年齢35 16 歳、男性21例、女性 12例。これらを緊急手術(急性 $A$ 型解離)12例(A群)、待機手術23例(B群)にわけ早期、遠隔成績を比較検討した。術 式は Bentall法19例(A群/B群=7/12)、Cabrol法7例(A群/B群=1/6)、Piehler法3例(A群/B群=2/1)、自己弁温存 法6例( $(A$ 群/B群=2/4)。併施術式は全弓部置換6例(A群)、冠動脈バイパス2例(A群)、MVR 2例(B群)、MVP 2例 (B群)、部分弓部置換2例(B群)。結果)早期死亡は A群のみで両側冠動脈虚血2例(16.6\%)を LOSで失った $(p=0.0335)$ 。遠隔期再手術12例(15手術)は胸腹部置換5例( $A$ 群/B群 $=2 / 3)$ 、全弓部置換 1 例( $(B$ 群)、下行置換 1 例 (B群)、PVDによる再基部置換3例(A群/B群=1/2)、MVP+TAP1例(A群)、MVP+CABG1例(A群)、MVR1例 (B群)、冠動脈瘤切除+CABG 1例(A群)、左室形成1例(B群)。遠隔期に突然死2例を認めた。累積生存率(A群 /B群)は1年83.3/100\%、3年83.3/100\%、5年83.3/89.2\%、10年83.3/89.2\%、15年83.3/82.3\%、20年; $83.3 / 74.8 \%(\mathrm{p}=0.9589) 、 心 \cdot 大$ 血管再手術回避率(A群/B群)は 1 年 $100 / 86.7 \% 、 3$ 年 $100 / 86.7 \% 、 5$ 年 


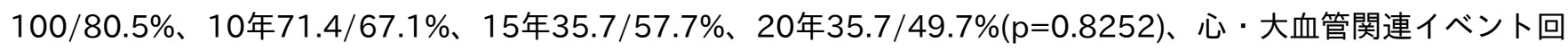
避率(A群/B群)は1年83.3/86.7\%、3年75/81.6\%、5年75.0/75.8\%、10年50.0/50.5\%、15年16.7/44.2\% 、20年 $0 / 33.2 \%(p=0.2348)$ といずれも両群間に差はなかったが、心・大血管関連イベントを高頻度に認め た。結論)早期成績は急性解離症例群でやや不良であったが、遠隔成績に差はみられなかった。経過中、心・大血 管関連イベントを高頻度に認めており、より慎重な経過観察と積極的な外科治療を行うべきと思われた。

(2019年2月11日(月) 14:50 16:40 A会場)

\section{[SY1-5] 遺伝性結合織疾患に対する David-V Reimplantationの中遠隔期予}

後

○山内 治雄 ${ }^{1}$ ，縄田 寛 ${ }^{1}$ ，木下 修 ${ }^{1}$ ，嶋田 正吾 ${ }^{1}$ ，安藤 政彦 ${ }^{1}$ ，峯岸 祥人 ${ }^{1}$ ，小前 兵衛 ${ }^{1}$ ，星野 康弘 ${ }^{1}$ ，木村 光利 ${ }^{1}$ ，平田 康隆 ${ }^{1}$ ， 大門 雅夫 ${ }^{2}$, 武田 憲文 ${ }^{2}$ ，小野 稔 ${ }^{1}$ (1. 東京大学 心臓外科, 2.東京大学 循環器内科)

【背景】自己弁機能が保たれた大動脈弁輪拡張症に対する自己弁温存大動脈基部置換術は標準的術式となりつつ あるが、遺伝性結合織疾患に対する術式選択には議論の余地がある。

【方法】当院で1998年から実施した自己弁温存大動脈基部置換術129例の内、2004年2月以降に標準術式とした David-V Reimplantation法107例を対象とし予後を解析した。

【結果】平均年齢は33歳、男性は75例（70\%）、Ghent基準を満たす広義マルファン症候群（MFS）は88例 (82\%)、その内11例は TGFBR1/2陽性のロイスディーツ症候群（LDS）だった。非 MFS症例は19例。術前大

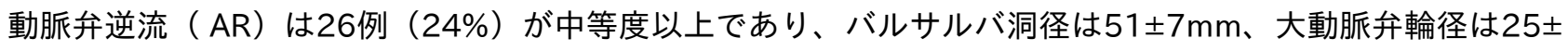
$3 m m$ だった。全て待機手術で施行し、開心術既往のある再開胸症例は5例だった。46例には David-V術中に大動 脈弁尖形成（中心性 plication 44例、交連部 suspension 5例）を追加した。手術関連死亡は無く、術後平均 フォロー期間6.0年（完遂率98\%）であった。全体コホートで術後生存率は5年96.2\%、10年94.4\%、心血管イベ ント回避率は5年 $81.5 \%$ 、10年68.6\%、中等度以上 AR回避率は5年 $88.7 \% 、 10$ 年76.5\%、大動脈弁置換回避率は

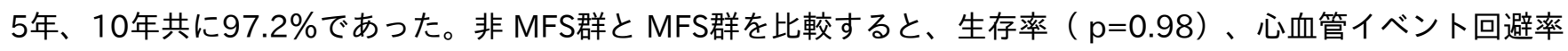
（ $p=0.91 ） に$ 差はなかったが、中等度以上AR回避率は非 MFS群では10年100\%に対し、MFS群では5年 86.4\%、10年71.6\%と低い傾向であった（ $p=0.052 ） 。$ 弁置換回避率は非 MFS群で10年84.6\%（2例：感染性 心内膜炎、血栓弁）、MFS群で10年100\%であった。心臓超音波検査にて大動脈弁尖の挙動を調べると、正常大 動脈弁で見られる slow closing distance（収縮後期の緩徐な閉鎖動作）は David-V術後も保たれ AR再発の有無で 差は認めなかった（各 $n=12 ） 。 M F S$ 群の術中の大動脈弁尖形成の有無と術後の中等度以上 AR再発率には有意な 相関関係を認めた（中心性 $p=0.04$ 、交連部 $p=0.03$ ）。一方、LDSを MFS群から独立して検討すると、生存率、 AR回避率に差はなかったが心血管イベント回避率は MFS（5年85.1\%）に比べ LDS群（5年63.0\%）では有意に 低かった（ $p=0.02 ） 。$

【結語】遺伝性結合織疾患に対する David-V Reimplantationは良好な成績だが、弁形成後形態の長期安定性には 課題が残り、術中の弁尖形成の追加は慎重な判断を要する。ロイスディーツ症候群は術後心血管合併症のリスク が高く定期的な画像検査が賢明である。

(2019年2月11日(月) 14:50 16:40 A会場)

\section{[SY1-6] 結合織疾患における大動脈基部病変に対する自己弁温存基部置換術 の有効性}

○中路 俊, 三浦 崇, 松丸一朗, 横瀬 昭豪, 田崎 雄一，嶋田 隆志，田口 寛子，田倉 雅之，宮永 竜弥，尾長谷 喜久子，江石 清行 (長崎大学病院)

【背景】Marfan症候群に代表される遺伝性結合織疾患(HCTD)において、大動脈基部病変に対する外科的治療と して Bentall手術や自己弁温存基部置換術(VSR)が行われており、当院では2013年以降、VSRを積極的に行ってい 
る。当院での HCTDにおける VSRの治療成績を Bentall手術と比較して検証する。【方法】1999年〜2017年で HCTD(Marfan症候群：13例、Ehlers-Danlos症候群:1例)を有する大動脈基部病変に対して14例の外科的治療を 行った。VSRを行った5例（V群）と、Bentall手術を行った9例(B群)に分け、患者背景、手術、術後早期死 亡、抗凝固関連合併症、大動脈弁に対する再手術について比較(V群 vs B群)した。【結果】年齢は37 12.3 歳 vs

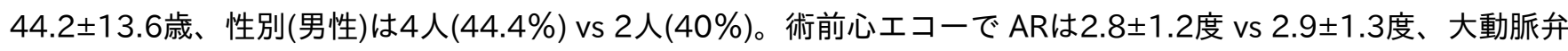
輪径は $25 \pm 2.5 \mathrm{~mm}$ vs $30.7 \pm 4.2 \mathrm{~mm}$ 、Valsalva洞径は $49 \pm 9.2 \mathrm{~mm}$ vs $58.9 \pm 12.7 \mathrm{~mm}$ 。手術時間は535.2 \pm 80 分 vs $385.1 \pm 94.4$ 分、人工心肺時間は285.8 448.9 分 vs $217 \pm 69.2$ 分。人工血管径は $26 \pm 0.8 \mathrm{~mm}$ vs $25 \pm 1.4 \mathrm{~mm}$ 。B群 での人工弁サイズは22 $1.5 \mathrm{~mm}$ であった。全弓部または部分弓部置換術を行ったのはV群で3例(60\%)、B群で 4例(44.4\%)であった。2013年以降に手術を行った6例のうち5例はVSRを行い、1例でVSRから Bentall手術に変 更した。術後早期死亡は両群ともなく、術後観察期間(38.5 22.6 月 v $115.6 \pm 53$ 月)において B 群でくも膜下出血 1例、脳梗塞 1 例、大腿皮下出血1例を認めたが、V群では出血および血栓性合併症はなく、大動脈弁に対する再手 術もなかった。【考察】当院では2013年以降、HCTDを有する大動脈基部病変に対してVSRを第1選択としてお り、手術時間、人工心肺時間は Bentall手術に比べて延長しているが、術後早期死亡はなく、抗凝固療法関連合併 症もなかった。Bentall手術と比べVSRでは大動脈弁への再手術の頻度が高いとの報告もあるが、当院での観察期 間において再手術はなかった。【結語】遺伝性結合織疾患に対する自己弁温存基部置換術は有効な治療手段とい える。

(2019年2月11日(月) 14:50 16:40 A会場)

\section{[SY1-7] マルファン症候群におけるステントグラフト治療の果たす役割}

$\mathrm{O}_{\text {島村 和男 }}{ }^{1}$, 倉谷 徹 $^{2}$ ，金 啓和 ${ }^{1}$ ，四條 崇之 ${ }^{2}$ ，政田 健太 ${ }^{1}$ ，前田 孝一 ${ }^{1}$ ，上野 高義 ${ }^{1}$ ，戸田 宏一 ${ }^{1}$ ，澤 芳樹 ${ }^{1}$ (1.大阪大学大 学院医学系研究科 心臓血管外科, 2.大阪大学大学院医学系研究科 低侵襲循環器医療学講座)

(背景) Marfan症候群(MFS)における大動脈病変は大動脈基部から腹部・大動脈分枝まで複数領域にまたがる広範囲 に及び、その治療は容易ではない。人工血管置換術は耐用性が高く第一選択治療として受け入れられている が、反面複数回・複数領域の心臓血管外科手術は侵襲度が大きいことも事実である。一方、近年広く行われてい るステントグラフト（SG）治療は低侵襲治療としての有益性も一部論じられているものの、結合織疾患に対する 使用は懐疑論が根強くあり、慎重な議論を要する。そこで今回、当院での治療経験から MFS治療における SG治療 の有効性を検討した。（対象と方法）2005-2018年に当院にて行なった MFS症例15症例に対する SG使用手術 34件（平均43.6才、男性55.8\%、大動脈解離 91.1\%、平均2.17(0-5)回の大血管手術既往あり）を対象とした。 SG治療は原則として基部から弓部までは人工血管置換を併用した上で中枢 landingとし、末梢側も人工血管置換 部を landingの第一選択とした。ただし下行大動脈治療長が長くなる場合は沗髄保護の観点から SGの一期的広範 囲留置を回避し、下行大動脈 nativeへの landingも併用した。SGサイズは thin slice CTによる大動脈トレース法 にて慎重にサイジングを行い、5-10\%の oversizeとなるよう厳密に選択した。術式は Hybrid弓部 11例、 Hybrid胸腹部 9 例、下行 TEVAR 10例、EVAR 4例であった。（結果）手術は技術的成功 $100 \%$ あり、周術期合 併症は脳梗塞0\%、脊髄障害0\%、急性腎不全0\%、気管切開 0\%、腸閉塞 2.9\%であった。30日以内死亡は 1/34(2.9\%)であり、死亡例は弓部治療後に治療待機中であった胸腹部領域の破裂で失った。遠隔期成績では平均

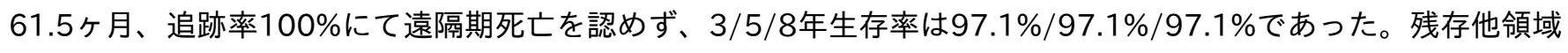
病変への追加治療を除く Aortic eventは 4 件（type 2 ELに対する塞栓術2例、人工血管感染 2例）であ り、3/5/8年 aortic event回避率は95.6\%/95.6\%/77.9\%であった。SG端での new tear、open conversionは認 めず、最終追跡時点で9/15例(60.0\%)が全大動脈領域の治療を要した。（結語）MFSに対する SG治療を組み込ん だ大動脈治療は、慎重な適応判断の下で有効に機能する可能性が示唆された。更なる遠隔期成績の追跡が必要で あるが、人工血管置換術を基幹とした治療戦略の中で、侵襲度を減じる選択肢として有用と考えられる。 
シンポジウム|末梢血管

\section{シンポジウム02}

\section{重症虚血肢に対する多職種でのチームアプローチ}

座長:駒井 宏好(関西医科大学総合医療センター),井上 芳徳(てとあしの血管クリニック東京)

2019年2月11日(月) 08:15〜 10:05 B会場 (岡山コンベンションセンター $2 F$ レプションホール)

(2019年2月11日(月) 08:15 10:05 B会場)

[SY2-1] 重症虚血肢に対しトータルフットケアを実践したチーム医療

Foot for Body、Body for Foot

森田一郎,磯田 竜太郎, 間野 正之 (川崎医科大学総合医療センター 血管外科)

近年、糖尿病、透析患者を中心に下肢血流障害から下肢切断に至る重症虚血肢の患者さんが後を絶ちません。そ の対策として、下肢血流障害の早期発見だけでなく、健康寿命を延ばす最も簡便で有効な手段としてフットケア が盛んに施行されるようになりました。しかしその生命予後は不良で、死因の多くが他の心血管病変で、

Polyvascular Diseaseの最たるものと考えるべきです。そこで、足病変を早期発見し、治療介入するフットケアの 形態も足だけでなく、全身を他職種で診ていくトータルフットケアへの変革が求められています。我々は院内の 他科・多職種と連携し、トータルフットケアをチーム医療として実践し、良好な成果を上げておりますので、報 告致します。

チーム構成は、血管外科、形成外科、糖尿内科、腎臓内科、リハビリ科と担当看護師、フットヶア指導士、理学 療法士、CVT、薬剤師、栄養師（NST）、ソーシャルワーカーです。毎週 1 回 PADカンファレンスを施行し、足 状態は勿論、脳・心臓などの他血管病の有無の CHECKと現状把握、糖尿病 - CKDの現状把握、創痛コント ロール、食事摂取状態、リハビリ進捗状況、退院後の follow upや連携について詳細に検討している。脳・心臓に 有意な異常を認めた場合は、脳卒中科・脳外科、循環器内科・心臓外科と密に連絡を取り、対処しておりま す。術後 QOL向上として (1)麻酔の低侵襲化、(2)創痛の軽減、(3)歩行機能の改善、(4)栄養状態の改善（NST介 入）、(5)残存する心血管病変のケアにチームとして取り組み、救肢率 $91 \%$ と成果をあげている。最近、中でも疼 痛管理が重要と考えており、痛みが強い患者には早期のオピオイドを使用している。これが奏効すると食事摂取 が向上し、創傷治癒か促進する。ひいてはリハビリが進み、全身状態の向上、早期退院へと繋がる。重症虚血肢 患者さんの入院期間は長く、その対策として入院時から、ソーシャルワーカーがチームに介入する事で、病 病・病診・病介の連携も円滑に進み、入院期間短縮に重要な役割を担っております。

また、岡山県内のフットケアの底上げと緊密な施設間連携を構築する目的で、岡山でフットケアに従事している 方の為に、平成30年10月に「岡山トータルフットケアを考える会」を立ち上げました。県内挙げて CLIの予 防・治療と健康寿命延長に邁進致します。

(2019年2月11日(月) 08:15 10:05 B会場)

[SY2-2] 重症虚血肢に対する急性期リハビリテーションの重要性

渡辺 健一 ${ }^{1,2}$ ，澁谷 卓 ${ }^{1,2}$ ，中村 隆，藤村 博信 ${ }^{4}$, 新谷 隆 ${ }^{5}$ ，三宅 啓介 ${ }^{1}$ ，上野 高義 ${ }^{1}$ ，戸田 宏一 ${ }^{1}$ ，倉谷 徹 ${ }^{1}$ ，澤 芳樹 ${ }^{1}$ (1.大 阪大学, 2.吹田徳洲会病院, 3.大阪労災病院, 4.市立豊中病院, 5.日本生命病院)

（はじめに）閉塞性動脈硬化症（PAD）の患者に対する運動療法は多く報告されているが、侵襲的治療介入早期 からの理学療法に関する報告は少ない。また、標準的なプロトロールもなく、担当医などの臨床的判断で進めら れてきたのが現状である。CLI症例に対する早期リハビリテーション介入による ADL維持・改善の効果を検証し た。（対象）大阪大学心臟血管外科末梢血管グループ関連施設のデータを後方視的に検討した。2014 年 1 月 より加療された WIfI stage 2、3、4 に相当するCLIは 91 例 129 肢（男性 74 例 99 肢、女性 17 例 30 肢、重複あり）であった。平均年齢は 73.6 歳、治療前の WIfl分類 WO が 10 肢、W 1、2、3 が 119 肢 であった。ADLは介護認定に用いられる日常生活自立度に準じて（自立0、介助 1 、車椅子 2 、寝たきり 3 ）と 
した。また、術後 3 日以内に理学療法士が介入した症例を早期介入群（E群：3 2 例）、それ以降の通常群（ L群：59 例）とし、術前と術後の日常生活自立度の変化、座位開始日数、歩行開始日数、病棟歩行自立日を比較 した。(結果)血管内治療のみ 56 肢、外科治療（ハイブリッド治療を含む） 73 肢であった。全体症例の ADLは術 前 $0: 66$ 肢、1 $: 12$ 肢、 $2: 42$ 肢、3:9肢、術後は $0: 65$ 肢、1:9肢、2:36 肢、3:19肢で あった。E群で術後の ADLが改善 3 例、不変 23 例、悪化 6 例、L群は改善 3 例、不変 50 例、悪化 6 例で あった。外科治療症例では E群 15 例で術後の ADLが改善 3 例、不変 10 例、悪化 2 例、L群 47 例では改善 1 例、不変 41 例、悪化 5 例であった。座位開始日数（ E群 2.1 日、L群 2.2 日、P $=$ N.S）、歩行開始日数（ E群 2.9 日、L群 7.1 日、 $P=0.02$ ) 、病棟歩行自立日（E群5.6日、L群 9.6 日、 $P=0.11$ ) で あった。（考察、まとめ）PADに対する血行再建術は術式により、切開部位や手術侵襲、術後管理が異なる。 CLI症例に対して侵襲的治療を施行した症例では、血流が改善し創傷治癒が得られ、積極的に早期リハビリ テーションを行うことにより ADLの維持、改善につながっていた。今後、下肢機能および身体機能低下をどのよ うに予防し、創治癒を妨げることなく歩行能を再獲得していくためには様々な職種による介入を行い、休止につ なげていく必要がある。

(2019年2月11日(月) 08:15 10:05 B会場)

\section{[SY2-3] 歩行機能回復を目指した多職種でのアプローチー歩行が術後 Bypass流量に与える影響一}

○岸本祐一郎, 藤原 義和, 岸本 望, 池田 陽祐, 徳留 純平, 笹見 強志, 掘江 弘夢, 大月 優貴, 大野原 岳史, 原田 真吾, 中 村 嘉伸, 西村 元延 (鳥取大学医学附属病院心臓血管外科)

【背景】集学的なチーム医療体制を構築することは重症下肢虚血（CLI）治療においてきわめて重要であり，歩行 機能回復にまで対応することで QOLを含めた治療成績向上が得られる可能性がある. 当院では2015年1月より創 治癒のみならず歩行機能回復を目指したPAD治療チーム体制を構築した. 本研究では当院でのチーム医療導入前 後の Amputation Free Survival（AFS）や歩行機能回復率の成績を比較するとともに, 歩行機能回復が Distal Bypass術後 graft流量に及ぼす影響について検討した.【方法】2011年1月～2018年7月に下腿病変を有すCLIに 対し血行再建を行った70例80肢において, チーム医療導入前（Pre群；20例26肢：2011年1月～2014年 12月），導入後（Post群；50例54肢：2015年1月～2018年7月）における治療内訳, AFS, 歩行機能回復率（ CLI以外の原因で歩行できないものを除外した術後歩行の有無）について検討した. また, Distal Bypass施行群に おいて術後1ヶ月以内に測定した graft流量の絶対值, および中期〜遠隔期に graft流量（術後1ヶ月）と比較し 80\%以下に低下する経時的流量低下の発生頻度, 大切断回避率について, 歩行機能の回復が得られた群（ W群）と得られなかった群（nonW群）で比較した.【結果】術前背景は Rutherford分類6が Pre群5肢 (19.2\%） / Post群17肢（31.5\%）（p=0.19），透析が Pre群11例（42.3\%）/ Post群28例（51.9\%） $\mathrm{p}=0.29$ ）であった．治療内訳は Pre群（EVT 23肢，Bypass 3肢）/ Post群（EVT 30肢，Bypass 24肢）（ $\mathrm{p}=0.004$ ）であり，Post群で Distal Bypassが有意に増加した. 3年の AFSは Pre群42\% / Post群70\%（ $\mathrm{p}=0.043)$ ，歩行機能回復率はPre群4肢 $(41.7 \%)$ / Post群22肢（71.0\%）（p=0.04）であり，AFS ·歩行機 能回復率は有意に改善した. Distal Bypass施行群において術後1か月以内に測定した graft流量は W 群 $(n=19)$ $140 \pm 56 / \operatorname{nonW}$ 群 $(n=8) 65 \pm 56 \mathrm{ml} / \mathrm{min}(\mathrm{p}=0.03)$ とW群で有意に高く, 平均観察期間 18.5 12.4 ヶ 月での経時 的流量低下発生頻度は W 群 1肢 (5.3\%) / nonW群 5肢（62.5\%）（p=0.004）と有意にW群で少なく, 大切断回 避率はW 群 100\% / nonW群 39\% (4肢で切断)であった.【考察】チーム医療導入後, AFSや歩行機能回復率は有 意に改善した. また, 術後 Bypass流量の術後変遷は歩行機能回復群が有意に優れており, QOL改善を含めた CLI長期治療成績向上において歩行機能回復を目指したチームアプローチが重要と考えられた. 


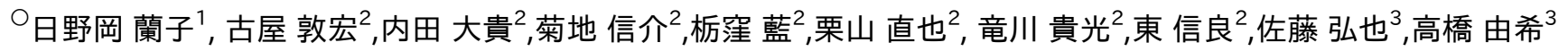
(1.旭川医科大学病院 看護部,2. 旭川医科大学 外科学講座血管外科,3.九旭川医科大学病院リハビリテーション部 )

重症虚血肢（以下 CLI）患者に対する治療戦略は医師の治療のみならず、多職種でのチームによるアプローチが不 可欠であることは近年コンセンサスとして周知され、コメディカルの様々な職種が専門性を発揮し、ディス カッションを通して患者の全人的医療を展開する形態へと変化してきている。

当院血管外科病棟では、入院時に既に感染壊疽を来しているCLI患者が多く、他院で切断を宣告されセカンドオ ピニオンを求めて来院し、栄養状態不良、ADL低下などの複合的な問題を抱える糖尿、維持透析の患者も多 い。血行再建後も広範囲組織欠損を伴い骨髄炎管理に長期を要する患者に対し、最終的なゴール設定を含めた長 期、短期目標を、達成までのプロセスが異なる職種がどう共有するかを考えていくのが、チームアプローチのー つの形態であると考える。

患者の入院後、医師は治療法を決定実施するとともに、他職種に対し栄養、理学療法、薬剤などの様々なこと を統合的に判断し指示をする。看護師は入院前の患者の日常生活の情報から退院後の生活遂行能力を判断し、他 職種と協働し生活遂行というゴールを目指す。壊疽を伴うCLI患者では、特定の医行為遂行が可能な看護師が毎日 の創傷処置及び管理方法の判断を行い医師に報告する。また医師および病棟看護師、回診に同行する理学療法士 間で適宜カンファレンスを行い情報を共有している。陰圧閉鎖療法では、実施時のスキンケアを始めとして、リ ハビリテーションへの支障が最小限となるためのデバイスの選択や、創の局所状態を見ての一時中断の判断は看 護師が行い医師に報告し指示の確認を行う。理学療法士とは頻回に情報交換を行い、日々変化する患者の心理を 含めた状態や、荷重、移譲の可否などの短期目標を共有し患者の最大限の機能を引き出すための装具やイン ソールについて相談しており、相互に患者に対するタイムリーな介入が可能となっている。

医学の治療のゴールは疾患の治癒であり、看護学のゴールは疾患の治癒も含めたその人の日常生活における満 足度という客観的測定が難しい評価指標で考慮する。看護師は、患者が治療を受けるために必要な生活上の環境 を整え、患者の持つ自然治癒力を最大限に引き出すための援助を行うとともに、治療を正しく受けるための意欲 を維持させることが役割であると考える。患者に対して異なる役割を持つ多職種が概念は異なっても健康という 同じ目標を共有するために重要なのは相互理解とコミュニケーションであると考える。

(2019年2月11日(月) 08:15 10:05 B会場)

[SY2-5] 理学療法士ができるチームアプローチ

○荒川優也 (松波総合病院 リハビリテーション技術室)

理学療法領域において重症下肢虚血に対する報告は極めて少なく、治療に対するエビデンスや介入方法における 標準化も示されたものはなく、手探りの状態と言って良い。当院の重症下肢虚血症例では潰瘍や感染を有してお りさらに重症化した例が多いことが特徵である。我々は、心臓血管外科の医師の指示のもとこのような症例に対 してもほぼ全例理学療法介入を行っている。下肢の虚血が外科的血行再建により解除されたのちより、歩行もし くは ADL能力の向上にむけ、潰瘍の有無、筋力や関節可動域の評価を行い治療介入していく。その中でも潰瘍な どの足の傷は荷重による圧を受けることで治癒が遷延してしまうことは知られており、局所の除圧をすることは 非常に重要である。しかしながら、それを意識しすぎて下腿免荷装具などにより過剰な免荷をすることは、荷重 によって期待できる下肢の血流量の増加を阻害することにもなりかねない。よって、重要なことは適切な局部の 除圧と接地可能な部分を見極め、最大限に生かし圧分散をすることにある。我々は、より必要最低限のフット ウェアを用いて最大限の工夫をして歩行の維持に努めている。さらに、理学療法における訓練内容やこのフット ウェアの選択と工夫は、主に理学療法士が進めたうえで医師に提案して許可を得て実施している。これ は、チームとして関わる上で非常に重要な点であると考える。治療に関して、医師からの指示待ちでなくコメ ディカルそれぞれが自分の専門性を生かし、考え、提案していくことで重症下肢虚血という難題にチームとして 挑むことが出来る。このような当院での取り組みを理学療法士の立場からデータを示しながら発信したい。 
(2019年2月11日(月) 08:15 10:05 B会場)

\section{[SY2-6] 当院診療放射線技師の EVT業務 〜チーム医療ボーダーレス化の勧 め}

○神田 耕治 (広島赤十字・原爆病院 中央放射線部血管撮影課)

昨今の血管撮影室業務においては「チーム医療」が不可欠となっています。当院の診療放射線技師の業務を紹介 するとともに、医師・看護師の業務を含めチーム医療の取り組み、それによって起こる問題点、これからの診療 放射線技師の業務について講演します。

当院の下肢治療においては、医師・看護師・診療放射線技師の 3 職種 3 名で行われています。患者搬入前に症 例についてのカンファレンスを行い、治療のゴール地点を共有することが重要です。搬入時には、バイタル機器 装着・下肢固定・消毒部分の確保・物品の準備等を看護師と放射線技師が気づいたところから準備します。ま た、手技中は医師 1 名であるため、放射線技師がセカンドオペレーターとして直介で携わり、同時に画像の表 示・読影まで関与します。そして、手技中に起こるゴール地点までの経路の変更も医師と相談しながら決定 し、より良い結果（ゴール）に導くための手助けをしています。

誰の仕事として線を引くことなく「だれがやってもいい仕事」は全員で関わるべきです。線を引くのは、独占 業務資格についてのみ個別の業務という事になります。コメディカルは、医師の業務をいかに軽減するかという 観点で存在する職種ですから、医師しかできない仕事だけを医師にしてもらうというのが当院のコンセプトとい うことになります。

診療放射線技師の業務は「放射線」を取り扱うのみでなく、良好な画像を撮影するための装置 - 固定等の工夫 画像のプロとしてのCTや MRIから得られた情報も加えた読影技術と考えます。また、将来的には業者頼みに なっているデバイスの知識を兼ね備え、医師に助言できる職種としてポジションを置いていきたいと思っていま す。 
シンポジウム|心不全・不整脈

\section{シンポジウム03}

\section{新たな時代に入った重症心不全に対する外科治療}

座長: 小野稔(東京大学医学部附属病院),福嶌 敎偉(国立循環器病研究センター病院)

2019年2月11日(月) 14:30～16:00 B会場 (岡山コンベンションセンター 2F レセプションホール)

(2019年2月11日(月) 14:30 16:00 B会場)

\section{[SY3-1] DT時代における EF}

○戸田 宏一,宮川 繁,吉川 泰司,秦 広樹,吉岡 大輔,甲斐沼 尚,樫山 紀幸,河村 拓史,河村 愛,上野 高義,倉谷 徹,澤 芳樹 (大阪大学 心臓血管外科)

【背景】虚血性僧帽弁閉鎖不全症に対しては CABGを行える場合は、低心機能であっても僧帽弁手術が推奨され ている。しかし心筋 viabilityが不明な非虚血性拡張型心筋症に伴う低心機能 DCM-MRでは手術適応には慎重にな らざるを得ない。今回我々は $\mathrm{EF}<35 \%$ の非虚血性 DCM-MR症例に対する僧帽弁手術の遠隔期成績を解析し手術 適応を検討した。

【方法】2007年から2016年に僧帽弁手術施行した EF＜35\%の非虚血性 DCM-MRの連続53症例を対象とし た。38\%は術前カテコラミン依存状態で、平均年齢：64歳、術前平均 BNP: 406 (229-620)、Crn: 1.0 (0.91.4)。心エコーでは術前 $E F, L V D d は$ 各々 $25 \pm 6 \%, 75 \pm 9 \mathrm{~mm}$ ，術前右心カテーテルでは cardiac index (Cl): $2.2 \pm 0.7$ $\mathrm{L} / \mathrm{min} / \mathrm{m} 2$, 平均肺動脈圧: $27 \pm 11 \mathrm{mmHg}$ と心拡大を伴った低心機能症例であった。15例(28\%)は人工弁輪による 弁輪縫縮(RMA)、13例(25\%)は RMA+乳頭筋間縫縮、25例(47\%)は弁下温存生体弁弁置換術を施行した。これら 症例において術後心機能、生存率、イベント回避率等を調べた。

【結果】術後16例(30\%)の症例でIABPを要したが、術後30日以内の死亡、脳合併症は認めなかった。LVAD装着

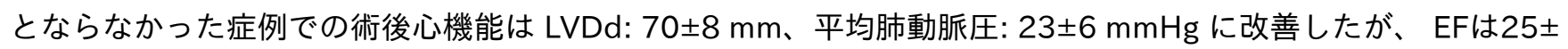
$11 \mathrm{~mm}$ と改善せず、Clも有意な改善認めなかった。術後平均観察期間3年で、心原死が11例、LVAD装着が 9例、非心原死が4例で、術後生存率は1年 : 88\%、3年 : 77\%、5年 : 62\%であった。遠隔期において NYHA classは術前 : 3.3 00.6 から2.3 \pm 0.9 に改善したが、BNPは有意な改善認めなかった。一方、死亡、LVAD装着、心 不全入院を合わせた複合イベントの回避率は、1年 : $58 \% 、 3$ 年 : $45 \% 、 5$ 年 : $26 \%$ 、術式による差を認め ず、有意な予測因子は術前左室一回拍出係数であった。

【結語】 Remodelingが進行した低心機能非虚血性 DCM-MRであっても、術式の工夫と十分な周術期管理に よって僧帽弁手術は安全に施行できた。しかしながら、遠隔期における心機能回復がそしい症例もあり、特に術 前左室一回拍出係数の低い症例では注意を要し、かかる症例では今後 LVAD-destination therapyも考慮すべきと 考えられた。

(2019年2月11日(月) 14:30 16:00 B会場)

\section{[SY3-2] INTERMACS Profile 1急性重症心不全に対する治療戦略}

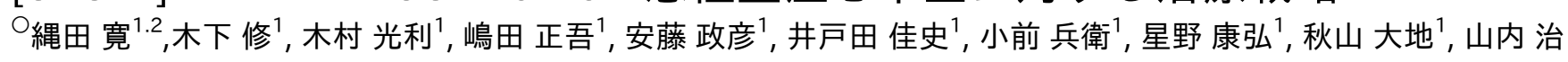
雄 $^{1}$, 小野 稔 ${ }^{1}$

(1.東京大学医学部附属病院 心臓外科,2.東京大学大学院医学系研究科 医療品質評価学講座 )

【背景】2011年の植込み型補助人工心臓の保険収載から7年が経過し、我が国の補助人工心臓（以下 VAD）治療 の成績は良好である。しかし INTERMACS Profile 1 に相当する急性の重症心不全に対する治療成績は今尚不良で あり、特に肺水腫を伴う急性両心不全症例に対する治療に難渋する。施設ごとに様々な治療の工夫が報告されて いるが、当施設では2016年以降、重症例において胸骨正中切開下 central ECMO+LV venting法を採用し、両心 
VAD装着を回避する戦略を採用している（ECMO: extracorporeal membrane oxygenation, LV: left ventricle)。

【目的】当施設における central ECMO+LV venting法（以下 CE/LV法）の治療成績を検証する。

【対象と方法】2016年1月から2018年8月の期間に当施設または他院で急性重症心不全に対してCE/LV法を施行 したのち当施設で治療を継続した成人10例（INTERMACS Profile 2相当の2例も含む）に対して後方視的に検討 を加えた。

【結果】CE/LV法施行時の年齢は39 7 歳、男女比6:4、原疾患は劇症型心筋炎5例、拡張型心筋症の急性増悪 5例。術前循環補助法は IABP+peripheral ECMO (pECMO) 補助5例、IABP補助4例、人工呼吸器管理のみ

1例。全例で術前の LVEFは20\%未満、中等度以上の肺うっ血の所見を示していた。pECMO装着例では、装着か ら CE/LV法までの期間は6.6 2.5（3〜9）日であった。CE/LV法導入後の転帰は直接離脱3例、3例は CE/LV法 補助のまま心臓移植適応を取得し植え込み型 VADを装着した。体外設置型 VAD装着が4例で、うち1例は離脱 し、2例は心臟移植適応取得後植込み型 VADに機種変更、1例は体外設置型 VAD補助中に脳梗塞で失った。 CE/LV法での補助期間は38 34 (7〜 108) 日であった。フォロー期間は18 18 ヶ月であった。

【結語】急性重症心不全に対する CE/LV法の成績は術前の重篤な全身状態を考慮すれば良好であり、回復もしく は次の機械的補助手段へのブリッジとして妥当な介入方法である。

(2019年2月11日(月) 14:30 16:00 B会場)

\section{[SY3-3] DTを前提とした Short term MCSから植込み式 LVADまでの戦略の}

\section{変化}

○藤田 知之, 福嶌 五月,松本 順彦, 福嶌 教偉,小林 順二郎 (国立循環器病研究センター 心臓外科)

Destination Therapy (DT)は、植込み型補助人工心臓（ILVAD）を心臓移植目的とせず、永久的に使用する治療 で、近く保険収載の可能性もある。DTを前提とした重症心不全に対する総括的な治療方針を立てなおす必要があ る。慢性心不全に対しての治療としては対象患者が広がる。具体的には、高齢、担癌患者などの他臓器の問題で 移植適応から外れるも予後が期待される患者が対象となる。成績を担保するためには、INTERMACS profile 3 以 下、J-VAD risk score で high riskに分類されないことなどの条件が必要である。当院でのILVAD（ N=152例）の 長期生存率は3年93\%であり、もともと厳格な患者選択があるため、J-VAD risk score で high riskであって も、3年93\%と良好な成績を示した。また、術後遠隔期の問題である、大動脈弁閉鎖不全症や感染、脳合併症は工 夫により低減できることが示された。

一方で、急性心不全患者は移植適応が不明であるため、より高度な MCS治療の選択に躊躇する場合があるが、 DTの受け皿があれば積極的に治療可能となる。これまでは、PCPS/IABPによりサポートされて紹介される患者 は、移植適応の可能性がなければ体外式 LVADの選択も難しかったが、今後は、より迅速に、Central-ECMO，体 外式 LVAD、BiVAD（両心補助），Impella（+/-ECMO）などの選択が可能となる。当院での劇症型心筋炎や急性 心筋梗塞など急性心不全に対するこれらの治療成績（ $N=24$ 例（2017年3月から2018年9月））は、30日生存率 92\%、離脱率50\%、ILVAD移行率29\%と良好であり、DTの出現でこれらの治療対象患者がさらに増加するもの と考えられる。

DTにより、急性、慢性問わず、重症心不全患者の治療選択が拡大し、予後を改善することが期待される。ますま す、DTの承認が待たれるところである。

(2019年2月11日(月) 14:30 16:00 B会場)

[SY3-4] 機械的循環補助の治療効果を最大限に引き出すために

塩瀬 明,牛島 智基, 藤田 智, 木村 聡, 園田 拓道, 大石 恭久, 帶刀 英樹, 田ノ上 禎久 (九州大学大学院医学研究 院 循環器外科学) 
【背景】機械的循環補助(MCS)は重症心不全外科治療において重要なツールである。本邦で行われている短期補助 を目的とした MCSにはIABP, 経皮的 VA ECMO (PCPS), そして, ニプロVADがある。2011年春からは心臓移 植へのブリッジ限定ではあるが長期補助かつ在宅医療を可能にする植込型 LVADが保険償還された。直に適応が適 正化され, Destination therapyが開始される予定である。適切な短期補助 MCSの使用がカギとなる急性心原性 ショック症例の多くが, ソケイ部から経皮的 VA ECMOが挿入されるが, 充分な補助流量が維持できずに臓器障害 が進行することが少なくない。下肢の動きに大きな制限があり, 立位, 歩行等のリハビリはできない。本施設で は，そのような症例に対し，体外循環装置用遠心ポンプを用いたセントラル ECMO，もしくは，VADへの移行を 行い, 有効な循環補助下の離床をめざす管理を行っている。保険適応のある体外設置型のニプロ VADはポンプ機

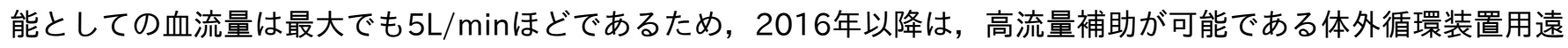
心ポンプを用いて体外設置型のVADを行っている。全身状態が人工心肺(CPB)に耐えられないほど不良である場合 や脳神経学的状態, 社会的背景が不明である場合はセントラル ECMOを, 意志確認ができており, CPBに耐える 場合はVADを選択し, セントラル ECMOで全身状態が改善後, VADに移行する。セントラル ECMO施行時, 心 機能が高度に低下して, 自己の大動脈弁の開放がなく, 肺うっ血が進行する場合, 左室脱血をY字接続で追加す る。この状態から, 右房脱血を抜去することで LVAD-ECMOに移行, 肺機能が改善した後に ECMOを外すことで LVADに移行する。VADは右心系の状態で, LVAD, もしくは, 両心補助人工心蔵 BiVADを選択し, 呼吸補助が必 要な場合は, LVAD-ECMO, BiVAD-ECMOとしている。送脱血路は, 人工血管, もしくは, 人工心肺用力 ニューレを用い, リハビリを念頭にして固定を強固にする工夫を行っている。【結果】急性心原性ショック21症 例中, 9症例にセントラル ECMO，7症例にBiVAD，5症例に LVADを選択した。セントラル ECMO 9例のうち 3例が BiVAD，5例が LVADに移行した。BiVAD症例はセントラル ECMOから移行した例を含めて，10例， LVAD症例は10例。結果は，6例が離脱，5例が植込型 LVADに移行し(BTB), 3例が補助継続中(BTB予定), 7例が 補助循環から離脱することなく死亡した。植込型 LVADは70症例に対し72回装着。ほぼ全例が在宅医療に移行 し, 装着後退院までの日数は平均で102日。6週間以内の再入院8例(11\%), 退院後在宅率は84\%。16例移植，1例 離脱生存，10例非離脱死亡，43例が補助継続中。累積生存率は 1 年 $97 \% ， 2$ 年91\%，3年87\%。【考察】本邦では VADに限らず, 海外で開発された最先端の医療機器の保険償還, 承認されるまでに生じる時間の遅れ（デバイ ス・ラグ）が問題となっているが，心臓移植の機会が限られている中で, 臨床使用可能なデバイスを活かし, MCSの治療効果を最大限に引き出す取り組みを続けている。

(2019年2月11日(月) 14:30 16:00 B会場)

\section{[SY3-5] DT時代に相応しい LVADとは？ EVAHEART2、チップレスカ ニューラ、EVADとその国際展開 \\ ○山崎 健二 ${ }^{1}$, 本村 禎 $^{2}$ (1. 北海道循環器病院 先進医療研究所, 2.EVAHEART Inc.)}

連続流型 LVADの普及により生命予後は格段に向上した。しかしながら脳血管障害、出血、感染症、等による再入 院回避率は1年時点で30\%と低值に留まり、これら合併症をいかに改善するかが DT時代における必須の要求事項 である。EVAHEARTは拍動効果を持ち補助能力が高いこと、せん断応力が小さいため von Willebrand因子の障害 が少なく出血性合併症が少ないこと、長期信頼性が高くデバイス血栓症が少ない等の利点を持つ。EVAHEAR 2で は勘合組立法によるケーシング肉厚の菲薄化、高効率化による駆動モータの小型化によりポンプ重量420 g $\rightarrow$ $262 \mathrm{~g}$ と大幅な小型軽量化を実現した。同時に耐久性を維持しつつ駆動ケーブルを断面積比で $36.7 \%$ 細径化し た。またメカニカルシール摺動面の表面修飾により潤滑状態が改善し、回転抵抗は格段に安定化した。

EVAHEART 2は2017年11月に薬事承認された。脳血管障害の克服に関しては、チップレスカニューラを開発し承 認申請を行った。左室内腔に突出する部分が無く、wedge thrombusの原因となるカニューラチップ周辺の血流 鬱帯や片当りを完全に回避可能な新機構である。EVAHEART 2+チップレスカニューラの組合せにより脳合併症 がより少ない DT時代に相応しいデバイスが誕生するものと期待される。感染症対策としては、皮膚貫通部の長期 安定したインターフェイスとして、多孔質チタンを用いた皮膚ボタンを開発し慢性動物実験にて評価中であ る。また EVAHEARTの分解再組立可能である利点を生かし、体外 VADとして用いる EVADプロジェクトも推進し ている。心移植適応取得が間に合わない症例においても使用可能で、植込型 VADの適応が得られ次第、互換性を 
持って植込型に組換え可能なシステムとなっている。駆動装置は植込型と同一な小型軽量タイプで、装置装着者 の利便性を高めている。海外展開について : 中国に関しては、EVAHEARTが2015年型式試験開始 ·「革新医療機 器」に認定、2017年中国 FDAに臨床治験申請、2018年1月より臨床治験が開始され現在までに9症例実施され全 例成功のエンドポイントを達成した。米国に関しては、EVAHEART 2 + チップレスカニューレでの治験が 2018年 FDAより開始許可が得られ、順次6施設で feasibility study が開始される予定である。

(2019年2月11日(月) 14:30 16:00 B会場)

\section{[SY3-6] 内科的治療抵抗性の高度 MRを伴う低心機能患者への外科治療 : 乳 頭筋接合を伴う MVR}

○石垣 隆弘，新宮 康栄，加藤 伸康，大岡 智学，加藤 裕貴，久保田 卓，松居 喜郎 (北海道大学病院)

背景;Destination therapyとして LVADが認可されつつある。しかしながら、現在のデバイスでは合併症による高 い再入院率や医療費など問題は多い。我々は高度僧帽弁機能不全（MR）を伴う非移植適応患者に対して、左室切 開を施行しない新術式 papillary muscle tugging approximation (PMTA)法を考案し施行している。目的;全ての内 科的治療に抵抗性の高度 MRを伴う拡張型心筋症患者に対して、LVAD以外の外科的選択肢として PMTAの有効性 を評価すること。方法;LVAD群は2011年から2017年の29症例のうち、中等度以上の MRを合併した14例。 PMTA群は2015年以降の12例。術前心機能は左室駆出率(LVEF)や Mw(slope in the preload recruitable stroke work relationship)を用いて評価。結果;LVAD群は全て非虚血性心筋症で、PMTA群は非虚血7例、虚血性5例。術 前左室拡張末期径（LVAD $72 \pm 6 \mathrm{~mm}$ vs. PMTA $71 \pm 10 \mathrm{~mm}$ ） と LVEF (24 $\pm 6 \%$ vs. $22 \pm 6 \%) 、 M w(35 \pm 10$ vs. $36 \pm$

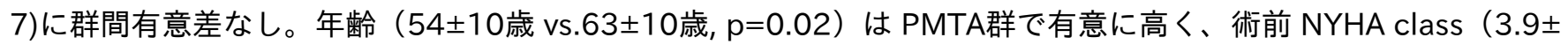
0.3 vs. $3.1 \pm 0.5, p=0.0007 ）$ LVAD群で有意に高かった。院内死亡は LVAD群2例、PMTA群は全例生存退 院。術後入院期間は LVAD群で有意に長く（LVAD群 112 \pm 35 日 vs. PMTA群39 \pm 16 日, $<<0.0001 ） 、 1$ 年再入院 回避率は LVAD群で有意に低かった（LVAD群 20\% vs. PMTA群 83\%, log-rank p=0.0012）。再入院の原因は、 PMTA群は出血性イベントの1例、LVAD群ではドライブライン感染が4例、3例が出血性イベント、機器不具合が 1例、その他2例。1年生存率は同等（ LVAD群 92\% vs. PMTA群 100\%, log-rank p=0.32）。結語;PMTA群は LVAD群と比較して1年生存率は同等であったが、LVAD群より入院期間が短く再入院が有意に少なかった。 PMTAは心移植が検討されるような内科的治療に抵抗性の高度 MRを伴う拡張型心筋症患者に対して中期的には有 用であり、選択肢の一つとなる可能性がある。 
シンポジウム|先天性

\section{シンポジウム04}

\section{小児及び成長期における弁膜症に対する手術}

座長:坂本 喜三郎(静岡県立こども病院),笠原 真悟(岡山大学)

2019年2月11日(月) 14:00 15:30 G会場 (A N Aクラウンプラザホテル $1 \mathrm{~F}$ 曲水)

(2019年2月11日(月) 14:00 15:30 G会場)

\section{[SY4-1] 肺動脈弁を含めた再右室流出路置換術の治療成績}

○小田 晋一郎, 中野 俊秀, 城尾 邦彦, 藤本 智子，合田 真海, 岡本 拓也，松田 健作，角 秀秋 (福岡市立こども病院心臓 血管外科)

[目的] 初回右室流出路置換(右室-肺動脈導管, transannular patch)術後, 成長期に再右室流出路置換術が必要となる 症例が増加している. 今回, 再右室流出路置換術の治療成績について検討した.[対象] 対象は1990年11月から 2018年8月までの301例. 初回右室流出路置換時の術式は生体弁付導管76例(25.2\%)，一弁付パッチ74例(24.6\%)， 弁なしパッチ61例(20.3\%)，fan-shaped valve付導管(山岸弁)54例(17.9\%)，術中作成弁付導管24例(8.0\%)，弁なし ePTFE 導管10例(3.3\%)と Contegra導管2例(0.7\%)であった. 初回右室流出路置換術時年齢中央值1.6歳(3日13歳), 体重8.7 kg(2.2-31 kg)であった. [結果] 再右室流出路置換の原因は, 右室流出路狭窄193例(64.1\%), 肺動脈弁 閉鎖不全88例(29.2\%)，狭窄兼閉鎖不全17例(5.7\%)とその他3例(1\%)であった. 再右室流出路置換術時年齢中央値 12.3(0.8-29.5)歳, 体重34.5(3.3-85)kgであった. 初回右室流出路置換術からの期間は8.6年(1ヶ月-23年)であった. 術式は fan-shaped valve付導管137例(45.5\%)，生体弁76例(25.3\%)，弁なし ePTFE 導管32例(10.6\%)，一弁付 パッチ27例(9.0\%)，術中作成弁付導管12例(4.0\%)，生体弁付導管9例(3.0\%)，弁なしパッチ6例(2.0\%)，機械弁1例 (0.3\%)と Contegra導管1例(0.3\%)であった. 再々右室流出路置換術は42例(14\%)に認め, 再々右室流出路置換術時 年齢中央値19(7-33)歳, 体重43.9(12.8-59.5)kgであった. 術式は生体弁21例(50\%), fan-shaped valve付導管16例 (38.1\%)，パッチ4例(9.5\%)と術中作成弁付導管 1 例(2.4\%)であった. 再々手術回避率は再右室流出路置換術後 10 年， 15年で79.8\%, 53.7\%であった. 再右室流出路置換術時の Fan-shaped valve付導管 $(20,22,24 \mathrm{~mm})$ と生体弁では， 再々手術はそれぞれ2例(2.3\%)，4例(5.3\%)に認め，Fan-shaped valve付導管では2例とも術後10年，生体弁では中央 值5.4(4-7)年で再々手術となった. 再々手術回避率は再右室流出路置換術後7年でそれぞれ $100 \%, 77.7 \%(\log$-rank test; P=0.008)であった. [結語] 成長期に再右室流出路置換術を必要とする症例が増加しているが, 近年は fanshaped valve付導管あるいは生体弁を選択していた. 主に10代の成長期での生体弁は5年程度の早期に再々置換が 必要となる症例もあり注意を要する. 一方, fan-shaped valve付導管の耐久性は妥当であり，10代における再右室流 出路置換術の第一選択となり得ると思われた.

(2019年2月11日(月) 14:00 15:30 G会場)

\section{[SY4-2] 小児僧帽弁置換術後の再弁置換の検討}

${ }^{\circ}$ 中村 悠治 ${ }^{1}$ ，帆足 孝也 ${ }^{1}$ ，中田 朋宏 ${ }^{1}$ ，島田 勝利 ${ }^{1}$ ，小森 元貴 ${ }^{1}$ ，中島 光一郎 ${ }^{2}$ ，黒菩 健一 ${ }^{2}$ ，白石 公 ${ }^{2}$ ，市川 肇 ${ }^{1}$ (1.国立循 環器病研究センター 小児心臓外科, 2.国立循環器病研究センター 小児循環器科)

【背景】小児期僧帽弁置換(MVR)では体格の問題から弁の一部を左房内へ縫着(translocation)して実際の弁輪以上 の大きさの弁を植え込むことがある. 成長に伴う人工弁-患者不適合(PPM)から遠隔期に再 MVRによる人工弁サイ ズアップが必要となるが，その適応や予後は不明な点が多い.【目的】小児期 MVR術後の再 MVRにおいて， translocationと人工弁サイズアップ，予後との関連を検討する.【方法】対象は1978年 2018年に当院にて二心室 修復での小児期 MVR後に人エ弁サイズアップを行った24例. 男女比は13:11，原疾患は房室中隔欠損9例，先天性 MR 6例, 先天性 MS 5例, 特発性僧帽弁腱索断裂4例で，初回 MVR時の年齢は平均 $1.9 \pm 2.0$ 歳, 体重は $8.8 \pm 4.7 \mathrm{~kg}$ ，再 MVR時の年齢は8.0 3.6 歳, 体重は22.5 $210.6 \mathrm{~kg}$ であった. 再 MVRの適応はパンヌス形成による MS 20例(左室流 出路狭窄合併 3 例), 血栓弁 1 例, 人工弁周囲感染1例, PPM 1例, 左室流出路狭窄単独 1 例であった.【結果】再 MVR後 
の生存率は1年91.7\%, 5年87.1\%, 10年87.1\%で，再々MVR回避率は 1 年91.7\%, 5年 $77.6 \%, 10$ 年 $71.1 \%$ で

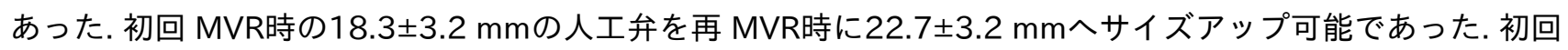
MVR - 再 MVR時の translocation施行例は9例 - 6例で, 初回 MVR時の translocation施行例では非施行例と比して 再 MVR時の人工弁輪径が有意に小さく(20.3 $\pm 1.9 \mathrm{~mm}$ vs $24.1 \pm 2.8 \mathrm{~mm}, \mathrm{p}=0.003)$ ，再々 MVRが有意に多かった (5/9 vs 1/15, p=0.007). 房室ブロックおよび手術関連死亡に有意差はなく，また再 MVR時の translocation施行 例では非施行例と比していずれも有意差はなかった. 初回 MVR後中央值7.7(2.6-4.7)年に施行した再 MVR術前の カテーテル $(\mathrm{n}=8)$ では初回 MVR時の translocationの有無では血行動態パラメータに有意差はなかったが, 再 MVR後中央值1.0(1.0-1.3)年に施行したカテーテル検査 $(n=8)$ では, 再 MVR時の translocation施行例では非施行 例に比して CVP，PCWP，LVEDPが有意に高値であった(CVP: $11.0 \pm 2.9 \mathrm{mmHg}$ vs $5.5 \pm 1.9 \mathrm{mmHg}, \mathrm{p}=0.009$ ， PCWP: $18.0 \pm 0.8 \mathrm{mmHg}$ vs $11.6 \pm 1.9 \mathrm{mmHg}, \mathrm{p}=0.001$, LVEDP: $17.0 \pm 1.0$ vs $9.2 \pm 1.3, \mathrm{p}=0.001)$ (Clや EFに は有意差なし).【考察】小児期における再 MVRは安全に施行でき,多くが2サイズアップ可能であった. 人工弁挿 入のための translocationはある一定の頻度で必要となるが, 静脈圧上昇や再置換のリスクとなる可能性があり，注 意が必要である.

(2019年2月11日(月) 14:00 15:30 G会場)

\section{[SY4-3] 小児期僧帽弁人工弁置換術後例の弁口面積指数からみた再手術時期 の検討}

櫻井一，野中 利通, 櫻井 寛久, 杉浦 純也, 大沢 拓哉, 和田 有星 (JCHO中京病院 心臓血管外科)

【目的】成人領域では有効弁口面積指数(EOAl: effective orifice area index)は, 人工弁サイズの選択において patient-prosthesis mismatch(PPM)回避のための重要な指標として確立され，とくに大動脈弁位で多く報告さ れ, 僧帽弁位でも報告が散見される. 一方小児では, 成長に伴いとくに僧帽弁位では再置換が必要になることが 多いが, 体表面積(BSA)の増加につれ経時的に EOAIが低下することになる. しかし, 小児人工弁術後の報告は少 なく, 自験例で弁口面積指数(GOAl: geometric orifice area index)を用い, 僧帽弁再置換の時期の指標となりうる かを検討した.【方法】1994年以後現在までの約24年間に，15歳以下で僧帽弁人工弁置換術(MVR)を行った2心 室性疾患の23例，35回の MVRのうち，当院で術後フォローし経時的なデータが得られた18例で， BSAの值から GOAIを算出し, あわせて心エコー上の僧帽弁流入速度(M flow)の経過と比較検討した. また GOAIが成長に伴う再

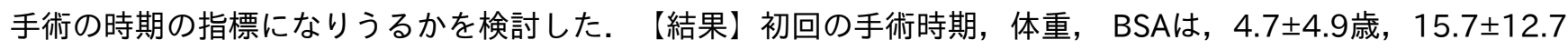
$\mathrm{kg}, 0.62 \pm 0.40 \mathrm{~m}^{2}$ で, 使用人工弁は, SJM 11例 (19: 1, 21:3, 23: 3, 25:2, 27: 1, 31: 1例), CM 6例(16: 3,

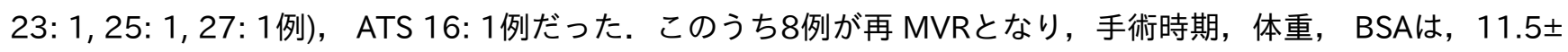
6.1歳, $34.0 \pm 19.0 \mathrm{~kg}, 1.11 \pm 0.32 \mathrm{~m}^{2}$ で, 使用人工弁は, $\operatorname{SJM}(23: 3,25: 1$ 例), ATS 3例(20, 22, 26: 各1例), OnX 27: 1例だった. 再置換8例では, GOAI, M flowは術前 $1.97 \pm 0.45 \mathrm{~cm}^{2} / \mathrm{m}^{2}, 2.38 \pm 0.40 \mathrm{~m} / \mathrm{s}$, 術後3.02 \pm $1.29 \mathrm{~cm}^{2} / \mathrm{m}^{2}, 1.88 \pm 0.40 \mathrm{~m} / \mathrm{s}$ 有意に改善していた. とくに成長に伴う僧帽弁の相対的狭窄のみで再置換と なった5例では全例 $2.0 \mathrm{~cm}^{2} / \mathrm{m}^{2}$ 以下だった. 非再置換10例では, 直近の GOI, M flowは, $2.29 \pm 0.42 \mathrm{~cm}^{2} / \mathrm{m}^{2}$ ， $1.97 \pm 0.39 \mathrm{~m} / \mathrm{s}$ だった.【結論】小児期 MVR例の成長に伴う再手術の時期として, 我々も以前報告したよう に, M flowが2.5〜2.7 m/s前後を超える頃とする報告が多く, 簡便に測定できる反面, 測定誤差も大きいという 難点がある. この点, GOAIは測定誤差が少なく, $2.0 \mathrm{~cm} 2 / \mathrm{m} 2$ を下回った頃が再手術の時期の指標となりえると 考えられた. しかし, 成長以外の人工弁機能不全による再手術時期の指標にはなりえず, M flowとあわせて評価 すれば有用と思われた.

(2019年2月11日(月) 14:00 15:30 G会場)

\section{[SY4-4] 新生児・乳児期重症大動脈弁狭窄に対する外科治療}

○村田 眞哉，長門 久雄，廣瀬 圭一，菅野 勝義，今井 健太，石道 基典，太田 恵介，猪飼 秋夫，坂本 喜三郎 (静岡県立こど も病院 心臓血管外科) 
【目的】新生児 ·乳児期早期の重症大動脈弁狭窄（ cAS）に対する大動脈弁形成術（AVP）は、Ross-Konno手 術や borderline HLHSに対する Norwood手術の代替術式と考えられる。同術式の成績を検討した。

【方法】対象は2013年から2017年にかけて当院で新生児・乳児期早期に AVPを施行した cASの7症例（すべて unicuspid aortic valve）。診断は、critical AS 6例（BVP後に ARを生じた1例を含む）、critical ASRが1例（ $A R$ は $2^{\circ}$ ）。並存病変は Shone複合兼 tAVSDが1例、imAVSDが1例。手術時日齢は6-104d（中央値 29d）、体重

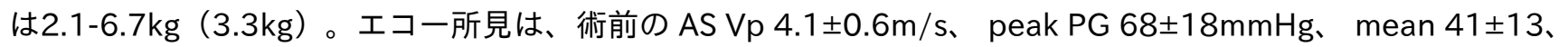
A弁輪正常比は $98 \pm 14 \%$ 、 LVEF 68 $11 \%$ であった。EFE様の左室心内膜輝度上昇を5例に認めた。術中所見 は、単一交連が L-R交連であるものが4例、N-L交連が2例、N-R交連が1例。 cASR症例は coronary hoodingによ るST低下を認めた。AVPの内容はすべて bicuspidizationで、弁切開のみが2例、交連切開と心膜による新交連の 作成が4例、心膜による2尖の完全作成が1例（cASR例）であった。

【成績】平均観察期間は3年5か月（17-58か月）。死亡例なし。術直後のエコーは、AR $2^{\circ} 1$ 例（交連切開のみ

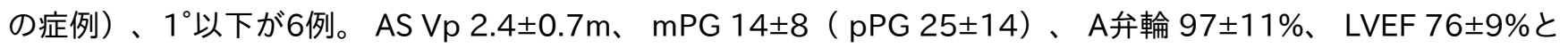

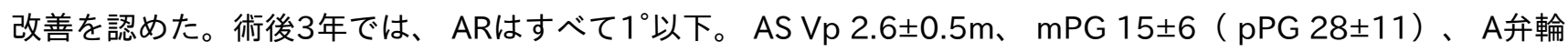
118 $12 \%$ 。再介入は、心膜による2尖の全弁尖作成を行った critical ASRに対し、生後9か月で弁尖の slicing 癒 着した交連の切開を行い、2歳時に Konno-AVR（ATS 16mm）を施行した。

【結論】いずれも新生児・乳児期早期に介入を要する重症例であったが成績は満足できるものであった。弁切開 のみの症例は術後 AS · ARが最も軽度で、固定心膜で全弁尖作成した症例は早期の再介入と人工弁置換を要した (図)。

(2019年2月11日(月) 14:00 15:30 G会場)

\section{[SY4-5] ロス手術後の新大動脈弁逆流に関する検討}

○山 祐樹, 新川武史, 松村 剛毅, 宝亀 亮悟, 小林 慶, 澤 真太郎, 日野阿斗務, 中前亨介，池原 大烈, 阿瀬孝治, 新浪 博士 (東京女子医科大学 心臟血管外科)

【目的】ロス手術後遠隔期に新大動脈弁閉鎖不全や大動脈基部の拡大が報告されている。【方法】1993年 11月から2012年2月までに当院でロス手術を行った連続73例 (男性 50例，女性 23例)を対象とし、術後生存と術 後遠隔期における新大動脈弁逆流および大動脈基部拡大の発生についての後方視的研究を行った。【結果】対 象のロス手術時の年齢（中央值）は12.1歳（0.4-39.1歳）。原疾患の内訳は大動脈弁狭窄兼閉鎖不全症32例，大 動脈弁閉鎖不全症24例, 大動脈弁狭窄症 15例, 活動期感染性心内膜炎 3例 (人工弁感染性心内膜炎 1 例), 人工弁機能 不全 1例。40例で既往手術歴があり、内訳はカテーテル的大動脈弁裂開術 20例, 大動脈弓部修復手術10例，直視 下大動脈弁交連部切開術 8例, 大動脈弁置換術 2例，大動脈弁形成術 2例，大動脈弁下狭窄解除術 2例。42例に大動 脈二尖弁を認めた。16例はロス/今野手術を行い、4例で大動脈弁下狭窄解除術を同時に施行。人工心肺時間は 214分 (143-346分)、大動脈遮断時間は152分 (97-472分)。ロス手術後早期死亡は1例（低心拍出量症候群）。 術後経過観察期間は 12.5 年（0.8-24.7年）でロス手術後15年の生存率は98.6\%。成人に達した女性 21 例中2例が 妊娠・出産を経験した。追跡可能な66例中、25例で中等度以上の新大動脈弁逆流（13例）、45mm以上の大動脈 基部拡大（6例）、または両方（6例）を認め、これらの回避率はロス手術後15年で54.2\%だった。この 25 例中 16例に機械弁を用いた大動脈弁置換術を施行した（うち3例は大動脈基部置換術も実施）。ロス手術から新大動脈 弁手術までの期間は7.9年（0.2-18.9年）。新大動脈弁手術時の年齢は18.0歳 (8.9-41.5歳)。使用した機械弁サイ ズの中央值は24mm (16-27mm)。新大動脈弁置換術後、6.7年（0.1-15.8年）の経過観察で、現在まで全例生存 している。ロス手術後の新大動脈弁逆流又は大動脈基部拡大に対する危険因子の検討では、男性が多い傾向 $(p=0.07)$ にあったが、ロス手術時の年齢，ロス術前のインターベンション，大動脈二尖弁，同時施行した今野手術や 弁下狭窄解除術については有意差は認めなかった。【結語】ロス手術の早期成績は良好であった。しかし、時 間経過と共に新大動脈弁逆流や大動脈基部拡大の発生を認め、継続的な加療が必要と考えられた。ロス手術後の 人工弁置換術は安全に施行でき、手術成績も良好と思われた。 
(2019年2月11日(月) 14:00 15:30 G会場)

\section{[SY4-6] 小児及び成長期における弁膜症手術：大動脈弁位人工弁置換術は回 避すべきか}

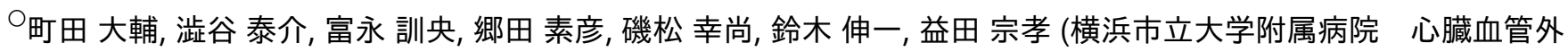
科)

【背景・目的】若年者における大動脈弁手術ではサイズと成長の観点から弁形成術が第一選択で、形成不能例で は Ross手術や自己心膜による弁再建術等が選択されるが、未だ確立された術式はなく遠隔期に問題を残す。人工 弁置換術はサイズや抗凝固療法の問題から回避されてきたが、人工弁の改良もありその適応は再検討すべきであ る。今回我々は小児期の大動脈弁位人工弁置換術後の成績を検討した。【対象・方法】2001年から2018年8月ま でに当院で大動脈弁位人工弁置換術（基部置換術を含む）を施行された18歳以下の20例を対象とし早期・遠隔期 成績を後方視的に検討した。【結果】手術時年齢、体重、BSAは其々中央值で

$14 （ 7 １ 8 ）$ 歳、46（18～65） k g、1.4（0.8～1.8） m2であった。原疾患は先天性 AS/ASRが7例、大動脈弁 下狭窄狭窄が1例、僧帽弁置換術後が1例、subarterial VSD合併 ARが3例、基部拡大を伴う ARが8例（動脈ス イッチ術後4例、結合織疾患 1 例、 aortitis2例、PA/DORV術後 1 例 ) であった。手術は AVRが10例(機械弁 8例、生体弁2例）、DVRが2例(機械弁）で、このうち弁輪拡大を7例（Nicks4例、modified

Manouguian1例、ManouguianDVR2例）で行った。基部置換（機械弁）は8例で行った。再手術症例例は弁置換 で7例（AVP術後5例、AVR術後1例、Ross術後1例）、基部置換で5例（動脈スイッチ術後4例、TCPC術後 1例）であった。弁サイズは弁置換で19（18-23）、基部置換で21（19-23）であった。手術死亡はな く、8.1（0.1〜11.6）年のフォローアップで遠隔期死亡を認めなかった。再手術は生体弁 AVR2例（生体弁機能 不全）と基部置換術後2例（結合織疾患 1 例：急性大動脈解離、aortitis 1 例：冠動脈仮性瘤破裂）で認めたが、機 械弁置換例では人工弁関連合併症は 1 例も認めなかった。生体弁再置換術後の2例を除く18例の直近の人工弁圧較 差(peak) は平均で23 $\pm 8 \mathrm{~m} \mathrm{~m} \mathrm{Hgであり、BNPは22} 215 \mathrm{pg} / \mathrm{ml}$ あった。【考察】若年者における大動脈弁位人 工弁置換術は多くの例で弁輪拡大が必要であったものの手術成績は良好であった。適切なサイズの弁が入ること で再手術回避を含めた遠隔期成績は機械弁では良好であり、選択肢の一つとなりうると思われた。

(2019年2月11日(月) 14:00 15:30 G会場)

[SY4-7] 10代 · 20代に対する大動脈弁、僧帽弁形成術の短期・長期成績

三浦 崇, 松丸一朗, 中路 俊, 横瀬 昭豪, 田崎 雄一，嶋田 隆志，田口 寛子，宮永 竜弥，田倉 雅之，村上 友悟，尾長谷 喜 久子, 江石 清行 (長崎大学病院 心臓血管外科)

（目的）若年者に対する大動脈弁、もしくは、僧帽弁形成術の短期・長期成績を報告すること。（対象と方 法）1999年4月から2018年6月までに左心系弁膜症に対して形成術をトライした10代・20代の若年者は37例 で、内、完遂できた36例（97.3\%）を対象とした。内訳は大動脈弁が14例、僧帽弁が22例、追跡率は94.4\%、追 跡期間は3.0（1.0-5.2）年であった。連続データは中央值（第1-第3分位）で示した。（結果）大動脈弁群の年齢 は20.5（15.8-26.8）歳で全例待機手術。弁疾患は ARが13例、ASRが1例で、弁形態は unicuspidが1例、 bicuspidが11例、tricuspidが2例であった。ファロー四徵症術後を 1 例、VSD閉鎖術後を1例含んだ。冕脱の形成 は central plication、弁尖縁 anchoring、CV-5による吊り上げで行い、弁輪拡大は当初 internal bandと external bandで矯正し、現在は Sleeve法による total root remodelingを行った。結果として、（1）弁尖形成と total root remodelingを5例、（2）弁尖形成と external bandを8例、（3）弁尖形成と internal bandを1例に施 行。体外循環時間は178（163.5-198）分、大動脈遮断時間は140.5（126-149）分であった。入院死亡と遠隔死 亡はなく、遠隔期の AR gradeは mild以下が11例（78.6\%）、 moderateが2例（14.3\%）、 severeが1例

(7.1\%)。Severe ARが再燃した1例（bicuspid）に対して術後9か月目に弁置換を施行した。僧帽弁群の年齢は 22 (18-26.5) 歳で、病因は感染性心内膜炎（IE）が8例（活動期5例・治癒期3例）、変性13例、先天性 1 例（ 
AVSD）。弁疾患はMRが21例で他の1例はMRを伴わないIEであった。活動期 IE5例は緊急・準緊急手術で あった。右小開胸による MICSアプローチを13例（59.0\%）に施行。形成手技は切除縫合が10例、人工腱索が 6例、腱索移植が1例、 edge to edge fixationが9例、弁輪形成が20例で、体外循環時間は138（119-

191） 分、大動脈遮断時間は75（68.8-96.5）分。入院死亡はなく、遠隔死亡は 1 例（4.5\% 突然死）。遠隔期の MR gradeは mild以下が20例 $(90.9 \%) 、$ moderateが1例 (4.5\%)、 severeが1例（4.5\%）であった。 Severe MRの1例（活動期 IE）は術後13日目に弁置換へ移行した。2例が術後妊娠出産を経験。（結語）若年者であって も僧帽弁形成術の根治性は良好であり、MICSを用いることで美容効果も得られていた。大動脈弁形成の難易度は 高く、逆流メカニズムに基づいた精緻な形成手技による治療成績向上が求められる。 
シンポジウム|虚血性

\section{シンポジウム 05}

\section{冠動脈バイパス術の静脈グラフトリバイバル}

座長:竹村 博文(金沢大学),高梨 秀一郎(榊原記念病院)

2019年2月11日(月) 09:50～11:50 |会場 (岡山県医師会館 $2 F$ 三木記念ホール)

(2019年2月11日(月) 09:50 11:50 |会場)

[SY5-1] 静脈グラフトのリバイバルは「歴史は繰り返す」か?

新浪 博士,森田 耕三,池田 昌弘, 駒ヶ嶺 正英, 池原 大烈, 齋藤 博之

(東京女子医科大学 心臓血管外科)

CABGの歴史は半世紀を過ぎたところで、当初 SVGによるACバイパスが標準であったが、LITAの長期開存性が証 明されて以来、動脈グラフトを多用した CABGが普及している。LITAに次ぐ第二の動脈グラフトとしては本邦で は RITAが最も頻用されており、特に両側内胸動脈を左冠動脈系に使用する事で生命予後を改善するとの報告もみ うけられる。しかしながら第三の動脈グラフトである橈骨動脈や右胃大網動脈が SVGより優れていることは証明 されていない。SVGは長期開存性が満足すべきものではないが、未だに多く用いられているグラフトであること も事実である。日本冠動脈外科学会の全国統計でみると SVGの使用率は2005年で29.8\%であったが年々増加傾向 を示し、2016年は42.1\%に使用されており、近年、SVGが使用される割合が増加している。積極的に SVGを使 用する根拠としては、no touch techniqueによる採取法の導入、内胸動脈の側枝で用いることによるNOの恩 恵、 external stentによる血管に対するストレス軽減などの工夫により長期開存性の向上が期待できることが挙げ られる。その一方で高齢者や透析患者などハイリスク患者が多くなり生命予後があまり長くないために動脈グラ フトよりも採取が簡便な SVGを用いるという消極的な理由も挙げられる。当院におけるグラフト選択は all arterial graftingを行うことを基本としているが、右冠動脈の狭窄が90\%未満、あるいは高齢者には SVGを使用し ている。当院で2017年10月から2018年9月の1年間で行なった連続単独 CABG症例は140例であり、 all arterial graftingは66\%、SVG使用は34\%であった。All arterial群と SVG使用群のバイパス枝数、糖尿病、透析比率に差 はなかったが手術時年齢は SVG使用群で有意に高齢であった。

当院における SVGの使用はどちらかというと消極的使用ということになるが今後 SVGの採取法などの工夫が長期 開存性を向上させることが証明されれば SVGの使用は多くなると考えられる。このことは半世紀前の CABGに逆 行することになるがこれが進歩であるか否かは当面は更なる長期間のクリニカルエビデンス次第と考える。

(2019年2月11日(月) 09:50～11:50 |会場)

\section{[SY5-2] No touch SVGの新たな可能性}

和田 賢二, 西川 幸作, 斎藤 大樹, 前田 恵, 尹 亮元, 恩賀 陽平, 清水 真行, 山中 将太, 吉尾 敬秀, 清水 篤, 内室 智也， 高梨 秀一郎 (榊原記念病院)

目的：当院では2015年より積極的に No touch technique法を用いている。当院における No touch SVGの治療成 績を評価した。方法 : 2014年1月から2017年2月までの当院における単独 CABG手術591例を対象とした。 RCA領域に SVGで血行再建を行っており、なおかつ術後 CAGが残っている296例を Conventional採取（Full touch法）SVG 166例（Full touch群）、No touch SVG130例（No touch群）に分けてグラフトの開存率を評 価した。また、術直後ならびに 1 年後遠隔期の CAGを用いて RCA吻合部の前後約 $1 \mathrm{~cm}$ 付近の最大 SVG径ならびに 冠動脈 native径を測定した。さらにSVGへの脂肪の付き具合を2段階に分けて（ $a$ 脂肪の付着が乏しい、 b静脈 の両側に約 $5 \mathrm{~mm}$ 程度以上の脂肪が付着している）造影の違いを評価した。結果：患者背景に有意差はなかった。 SVG早期開存率は（以下 Full touch群：No touch群）98.8\%：100\%（ $p=0.136 ）$ だが、遠隔期開存率は 87.1\% : 99.2\%（ $p<0.001 ）$ で No touch SVGで有意に開存率が良かった。また、術直後の SVG径は3.86 
$1.06 \mathrm{~mm}: 3.11 \pm 0.64 \mathrm{~mm}(\mathrm{p}<0.001)$ で優位に No touch SVG径が細かった。遠隔期の SVG径は2.09 $0.10 \mathrm{~mm}: 2.37 \pm 0.17 \mathrm{~mm}(p=0.166)$ 、変化量は $-1.52 \pm 0.09 \mathrm{~mm}:-0.77 \pm 0.13 \mathrm{~mm}(p<0.001)$ で両群の SVG径は共に経過でより細くなるも no touch SVGが変化量が少なく有意に内径が保たれていた。冠動脈 native径 は1.63 $\pm 0.03 \mathrm{~mm}: 1.76 \pm 0.04 \mathrm{~mm}(\mathrm{p}=0.01)$ 、遠隔期の native径は $1.24 \pm 0.06 \mathrm{~mm}: 1.77 \pm 0.10 \mathrm{~mm} （ \mathrm{p}<$ 0.001）、変化量はー0.19 $\pm 0.03 \mathrm{~mm}: 0.06 \pm 0.05 \mathrm{~mm}$ で No touch SVG群では native内径が保たれた。また no touch SVG群内の脂肪で分類すると（上記 a : b） SVG径変化量は-0.70 $\pm 0.20 \mathrm{~mm} ：-0.82 \pm 0.15 \mathrm{~mm}$ （ $p=0.645)$ 、冠動脈 native変化量は-0,13 $\pm 0.11 \mathrm{~mm}: 0.16 \pm 0.08 \mathrm{~mm} （ p<0.05 ）$ 脂肪が多いほど冠動脈の径は 保たれる傾向となった。結語：No touch SVGは Full touch SVGと比較して遠隔期開存率は有意に良好で あった。また No touch SVG群ではよりグラフト内径かつ native血管の狭窄の進行を抑える働きがあり、脂肪が多 いほどその働きが強かった。No touch SVGで遠隔開存に positiveな働きが示唆された。

(2019年2月11日(月) 09:50 11:50 |会場)

\section{[SY5-3] CABGにおける No-touch SVGの可能性}

$\mathrm{O}_{\text {恒吉 }}$ 裕史 $^{1}$ ，小宮 達彦 ${ }^{2}$, 植木 力 $^{1}$ ，山中 憲 ${ }^{1}$, 平野 雅大 ${ }^{1}$ (1. 静岡県立総合病院 心臓血管外科, 2. 倉敷中央病院 心 臓血管外科)

【はじめに】CABGにおいて、動脈グラフトの使用は遠隔成績の向上に寄与することに異論はないが、no-touch techniqueで採取した SVG(NT-SVG)が動脈グラフトに匹敵する開存率であると最近報告されてい

る。我々は、2013年より NT-SVGを積極的に使用しており、中期遠隔期の開存率も含めた当院での臨床成績を報 告する。

【方法】2013年8月から2018年10月までに倉敷中央病院、静岡県立総合病院で私自身が用いた NT-SVGは計 83例で、SVGの採取は主に下腿から行っている。術前にェコー、CT等で SVGを評価し、径が $2 \mathrm{~mm}$ 以上あり、静 脈瘤のないことを確認している。皮膚切開は下腿で3カ所のスキップとして、静脈から $5 \mathrm{~mm}$ 程度離した周囲組織 ごと採取する。通常採取法で用いるシリンジによる拡張は行わず、OPCABの場合は大腿動脈にシースを挿入して NT-SVGを接続し、自己の動脈圧で自然拡張した。採取後は創部にドレーンを留置し、術中から弾性包帯で巻き上 げを行った。術後入院中に、ほぼ全例で CAGによるグラフト評価を行った。術後遠隔期には数年毎にグラフト評 価を冠動脈 CTで行った。

【結果】NT-SVG使用症例の平均年齢は $66 \pm 10$ 歳、OPCAB率は $82 \%$ 。周術期の出血再開胸、心筋梗塞、死亡はな

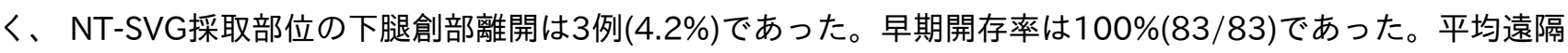
フォロー期間は $30 \pm 15$ か（3-50ヶ月）で2例の遠隔死亡（精神病悪化 1 例、消化管出血 1 例）を認めた。術後遠 隔期にグラフトの開存を評価した症例は17例で、術後29土11ヶ月（7-62か月）の遠隔開存率も 100\%(17/17)で あった。同時期に使用した通常採取方法の SVGの早期グラフト開存率は $97.5 \%(234 / 240)$ であり、統計学的有意 差はないものの NT-SVGの方がグラフト開存率が良かった。

【まとめ】No-touch SVGの早期グラフト閉塞はなく、通常採取法の SVGよりも開存率が良い印象であった。術 後平均3年時点での NT-SVGの中期開存率も100\%であった。NT-SVGは、通常採取法の SVGよりも遠隔期開存率 が向上する可能性があると思われる。

(2019年2月11日(月) 09:50 11:50 |会場)

\section{[SY5-4] No touch SVGの短期臨床成績と採取部合併症に関する検討}

菅谷 彰, 村岡 新, 相澤 啓，上杉知資，阿久津博彦，高澤一平，佐藤 弘隆，川人 宏次 (自治医科大学心臓血管外科)

[背景] Sauzaらによって提唱された no touch(NT)法は、SVGを周囲脂肪織と一塊として採取し用手的圧拡張を行 わないため、遠隔開存が期待できるとされる一方で、採取部の合併症に関する検討は少ない。本研究では、 NTSVGの短期臨床成績を検討し現時点での問題点を検討した。[対象] 2016年8月から2018 年8月までの105症例 


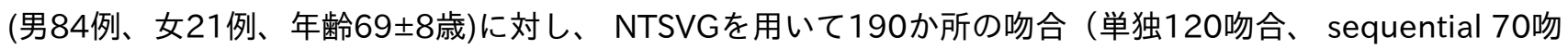
合）を行った。待機手術92例(88\%)、緊急手術13例(12\%)であった。単独 CABG83例、合併手術22例で、合併手 術の内訳は、AVR 7例、MVR(P) 5例、左室瘤手術 1例、その他 9例であった。術前の合併疾患は、糖尿病 $6 \%$ 、透析中の慢性腎不全 $23 \%$ 、高血圧 $94 \%$ 、高脂血症65\%、喫煙68\%であった。吻合部中枢の病変重症度は 75\%狭窄23\%、90\%狭窄27\%、99\%狭窄18\%、完全閉塞18\%であった。NTSVG採取部位は下腿部124例 (82\%)、大腿部26例 (17\%)で、採取部皮下には closed suction drainを留置し管理した。[結果] 病院死亡は 1/105例 (1.0\%) (透析患者の緊急 CABG症例。死因：敗血症)であった。ICU滞在期間は6 5 5.5日、入院期間は 27士26日であった。CABG術式は心停止下 55例、on pump beating38例、OPCABG12例で、平均吻合枝数は $3.3 \pm 0.9$ 枝、吻合箇所は、 $\operatorname{LAD}(5), \mathrm{D}(25), \mathrm{Lcx}(72), \mathrm{RCA}(88)$ であった。グラフト流量は、単独 $44 \pm 24 \mathrm{ml} / \mathrm{min}(\mathrm{P} .1$ 2.1)、 sequential $54 \pm 25 \mathrm{ml} / \mathrm{min}(P . I$ 1.9)で、RCAへの吻合のグラフト流量は $45 \pm 21 \mathrm{ml} / \mathrm{min}(P . I$ 2.3)、LAD

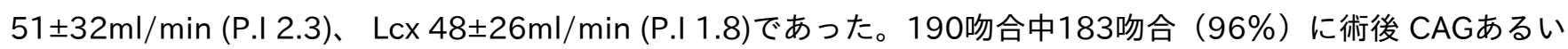
は CTを施行した結果、開存率は181/183(99\%)であった。冠動脈造影を施行した75例においては、

FitzGibbon分類 grade A 135例(99\%)、grade O 2例(1\%)であった。グラフト採取部合併症は11/155肢(14\%)に 認められた。内訳は蜂窩織炎6例、創部離開2例、血腫2例、静脈炎 1 例で、いずれもドレナージ、VAC療法、抗

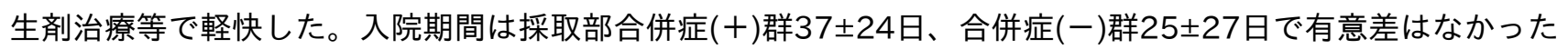
$(p=0.176)$ 。採取部合併症の有無に関して術前因子（年齢、性、高血圧、糖尿病、透析、高脂血症、術前左室駆出 率、IABPの有無、人工心肺使用の有無）を検討したが、有意な予測因子はなかった。[結語] NTSVGの短期成績は 良好であったが、グラフト採取部の合併症が多い傾向があり、今後の検討を要する。

(2019年2月11日(月) 09:50 11:50 |会場)

\section{[SY5-5] 大伏在静脈の採取法の工夫による長期開存改善の可能性}

三島健人，江口 昭治，大西 遼，加藤 香，長澤 綾子，岡本竹司，白石 修一，土田 正則 (新潟大学)

「はじめに」 冠動脈バイパス手術は、動脈グラフトが多数用いられる以前は主に大伏在静脈により行われてき た。動脈グラフトはその優位性が多数報告されているものの、大伏在静脈グラフトに関しても採取法の改善など で遠隔開存率を上昇させる可能性があるとする報告を認めている。当科では、より低侵襲にするべく近年は創部 を極力小さくしたり内視鏡での大伏在静脈採取を行っているが、それより以前は可能な限り周囲組織をつけ愛護 的に扱い動脈血で最小限の圧で灌流するといったまさに最近報告された大伏在静脈のより良い採取法とされる方 法で採取していた。今回、当時の採取法による大伏在静脈グラフトについて再検討を行った。「対象と方法」 対象は1977年1月から1998年までの22年間で施行された冠動脈バイパス症例。緊急手術、他の心臓手術併施例は 除外した。前下行枝に対する大伏在静脈グラフト（S群）と内胸動脈（I群）を用いたバイパスについてその成績 を比較検討した。「結果」同期間に除外例を除いたバイパス手術症例は266例であった。平均年齢は61 49.1 歳 男性78\%、2例のみ心拍動下手術で他人工心肺下に心停止での手術であった。バイパス本数は平均2.15本。入院 死亡を15例5.3\%に認めた。術後の造影は直後の造影検査結果を179例（67\%）、1年程度経過した結果を102例

（38\%）で得た。S群は136例、I群は123例であったが、手術日の中央值は S 群が1986年11月、I群が1995年 6月と 10 年近くの差があった。両群とも直後の開存率は85\%で差を認めなかった。1年後の造影では、S群であら たに $14.8 \%$ の閉塞を認め、I群は9.4\%の閉塞を認めた（N.S.）。以後の造影検査で開存が確認された症例は S群 15 例 I群21例認め、うち10年以上経過後の開存確認例を S群6例 I群9例に認めた（N.S.）が、1年以上経過後に閉 塞が確認された症例は S 群・ I群ともに2例しか認めなかった。1年以上経過後の造影検査結果を得ることができた 例では、S群で88\%、I群が91\%で開存を認める結果であった（N.S.）。「まとめ」大伏在静脈による前下行 枝へのバイパスの成績と内胸動脈によるバイパスの成績との間に有意な差は認められなかった。 約20年から 40年前の症例であり追跡できた症例に限りはあったが、周囲組織を意識して残し過拡張はせず愛護的に扱うよう にした大伏在静脈グラフトは内胸動脈に近い長期開存を望める可能性があると考えられた。 


\section{[SY5-6] Proximal First法 : No-touch法で採取した大伏在静脈グラフトに最} 適な吻合戦略

○浜崎 安純, 内田 徹郎, 黒田 吉則, 水本 雅弘, 山下 淳, 廣岡 秀人, 石澤 愛, 赤羽根 健太郎, 貞弘 光章 (山形大学 医学 部 外科学第二講座)

【背景】大伏在静脈 (SVG)は本邦で最も使われているグラフトであるが、長期開存性という課題があった。 Souzaの報告した No-touch法はこの問題を解決できる可能性があり、当科では2016年10月から No-touch SVG (NT-SVG)を採用した。Souzaの原法は conventionalな冠動脈バイパス (CABG)で、オフポンプ CABG (OPCAB)の 盛んな本邦に適しているとは言いがたい。また、使用してみると NT-SVGにはキンクがわかりにくい、十分な前拡 張が得られないと吻合しにくいなどの問題があることがわかってきた。そこで、種々の改良を加え心拍動下 CABGに最適な NT-SVGの使用法を確立した。【方法と結果】一般的に free graftは末梢側から吻合する術者が多 く、中枢側吻合を先行する術者は少数派である。われわれも当初は末梢側吻合を先行していたが、2017年5月か ら SVGの中枢側吻合を先行する Proximal First法を導入し、同年10月から標準術式とした。その結果、大腿動脈 に挿入したカニューレにSVGを接続して行う前拡張が不要になり、上行大動脈からの直接的で効果的な前拡張が 可能になった。使用開始から2018年7月までの46例、60本の NT-SVGを用いた CABGの31例、43本に Proximal First法を適用した。9例は急性冠症候群でIABP補助下、3例は左室駆出率30\%未満であった。NT-SVGはまず中枢 側吻合を先行し、断端をクランプして前拡張させておく。吻合直後に拍動性の free flowが得られるので、中枢側 吻合の問題をすぐに発見できる。前拡張の間に側枝からの出血は容易に発見可能で、標的血管への長さ調節が容 易で、キンクやねじれがあれば free flowが減少·消失するので、キンクとねじれを防止できる。 Sequential吻合 の場合は次の吻合に移る前に直前の吻合に問題がないことを確認可能である。1ヶ所吻合するたびに血流供給され るため、脱転中の血行動態維持も容易である。対象のうち11例は急性冠症候群や低心機能のハイリスク例で あったが、全例、術中血行動態は安定していた。早期開存率は95.0\%であった。【結論】 Proximal First法に は、1) 枝からの出血の発見が容易、2) グラフトの長さ調節が容易、3) キンクやねじれ、中枢側吻合や近位の sequential吻合のトラブルを予防可能、4) 1本吻合するたびに虚血領域に血流を供給可能、以上の利点があり、 NT-SVGの欠点を補い、利点を最大限に発揮させるのに最適な吻合戦略である。

(2019年2月11日(月) 09:50 11:50 |会場)

\section{[SY5-7] CABG 静脈グラフトの長期開存性と使用特性の検討}

岡田 隆之, 金本 真也, 善甫 宣哉, 細野 光治, 桑内 慎太郎, 谷口 直樹, 川副 浩平, 湊 直樹 (関西医科大学心臓血管外 科)

当院で2009年4月から2017年12月までに合併手術を含む407例にCABGを施行した。 単独 CABGは290例で、平均69.2（35-90）歳で平均3.1（1-6）枝吻合。内訳は緊急・準緊急28例を含み、 Conventional 10、On-pump beating 44、Off-pump 236例。緊急症例を含む入院死亡は5例（1.7\%）で、遠隔 期死亡（median48, max101ヶ月）は32例。遠隔期生存率は90.0\%。Coronary CT等の造影検査で265 例のグラ フト開存性を検討した。

単独 CABGでの使用グラフトは、内胸動脈 IMA 269 (LIMA 259, RIMA 45, BIMA 40)、大伏在静脈 SVG 211、橈 骨動脈 RA 152、胃大網動脈 GEA 46枝。IMA, SVG, RA, GEAの順に早期開存率は98.1, 93.8, 91.4, 93.5\%、中遠 隔期（ median48, max101ヶ月）開存率は96.3，89.1，86.2,91.3\%であり、SVGは RAより高い開存率を示し た。

OPCABを基本術式として完全血行再建を図るために、性状不良病変に対しては LADのみならず Cxや RCAにも積 極的に Onlay法を施行した。Onlay法は56例66枝（Endarterectomyは18例を含む21枝）に施行した。Onlay法 の使用グラフトと開存数は IMA 38/38, SVG 12/13, RA 7/9, GEA5/6枝で、各々の開存率は $100,92,77,73 \%$ と SVGはIMAに次いで良好であった。SVグラフトでも favorable remodelingとして良好な吻合部形態で開存するこ とを確認した。

SVGの高開存性への工夫として、期間前半（～2014）は用手加圧は軽度とし、SVG壁に平行となるように側枝を 
その根元で結紮し、静脈瘤は斜切除・端々吻合しスムースな内腔確保に努めた。後半（2015～）ではSVGの用手 的な拡張加圧をせず、総大腿動脈穿刺シースからの動脈圧のみで前拡張を行い、内皮機能の温存に努め

た。2017.7月よりSVG分枝血管の本幹近傍での処理をせず、no-touch pedicled SVGとして採取している。後半 群は遠隔期成績が待たれるが、中期以降の閉塞率はRAより低い傾向にある。 pedicled SVGにより外膜側からの メカニカルストレスが抑制され開存性が向上するかは検討を要する。

また、SVGが動脈化する経時的劣化が示唆されてきたが、SVG-RCA吻合後の剖検自験例を評価した。吻合部は SVGから native RCAの全周性に内皮再生がみられた。SVG免染にて静脈特性の Ephrin type-B receptor 4は夕ン パク発現が低下していたが、動脈特性の Ephrin B2の発現性は高まらず動脈グラフトの特性獲得には至っていな かった。

上記に考察を加えて、CABG静脈グラフトの長期開存性と使用特性について検討する。 
シンポジウム | 弁膜症

\section{シンポジゥム06}

\section{Atrial functional MRの最新の治療方針}

座長:柴田 利彦(大阪市立大学), 濱野 公一(山口大学)

2019年2月12日(火) 08:30 10:30 G会場 (A N Aクラゥンプラザホテル $1 \mathrm{~F}$ 曲水)

(2019年2月12日(火) 08:30 10:30 G会場)

[SY6-1] 心房性機能性僧帽弁逆流と三尖弁逆流の頻度 ·予後, 機序

○阿部 幸雄 ${ }^{1}$ ，赤松加奈子 ${ }^{1}$ ，伊東 風童 ${ }^{1}$ ，野村 菜々香 ${ }^{1}$ ，松村 嘉起 ${ }^{1}$ ，成子 隆彦 ${ }^{1}$ ，高橋 洋介 ${ }^{2}$ ，佐々木 康之 ${ }^{1}$ ，臀山 稔 ${ }^{2}$ ，柴 田 利彦 $^{2}$ (1.大阪市立総合医療センター循環器内科, 2.大阪市立大学)

機能性僧帽弁逆流（MR）の主因は, 左室の拡大および収縮不全による tethering-tentingであるとされてきた.し かし長期持続性心房細動（AF）例では，左室収縮能低下がないにもかかわらず，心房拡大に続発して機能性 MRおよび機能性三尖弁逆流（TR）が生じ得る. AF例におけるこれらの弁逆流は, それぞれ atrial functional MR ( AFMR)， atrial functional TR（AFTR）と呼ばれる. 我々は超音波検査室で2年間に心ェコ一図検査を受 けた11,021例における AFMRと AFTRの頻度と予後への影響を後ろ向きに調べた. 検査時に持続性 AFで他の基礎 心疾患がなく, 左室駆出率が50\%以上だったのは298例だった．そのうち中等度以上の非器質性 MRと非器質性 TRを有したのは，それぞれ24例（8.1\%），44例（15\%）といずれも少なかった.しかし，10年以上の長期持続 性 AF例に限ると，それぞれ28\%，25\%と頻度が高くなった. 平均24か月の観察期間で35例（12\%）に心イベン 卜 (心臓死5例, 心不全入院23例, 僧帽弁・三尖弁手術7例) が生じた. MRとTRの重症度はいずれも心イベント の独立した予測因子だった. カプランマイヤー解析において，MR TRのいずれもが中等度以上である例では 24か月のイベント回避率が $21 \%$ と低かった. 以上の結果から, 長期持続性 AF例では有意な AFMRおよび AFTRが 認められることは稀ではなく，それらが合併する例では心不全イベントが非常に多いことがわかった. した がって，AFに続発するこれらの弁逆流は治療ターゲットとして認識されるべきである. また, 3D経食道心エ コ一図を用いて AFMR例の解剖学的特徵を調べたところ, 左房と僧帽弁輪が大きく, 僧帽弁前尖は動きに障害を 受けず収縮期に弁輪面に沿って平らになっていた. 一方, 僧帽弁後尖は先端が左室後壁方向に湾曲して閉鎖が障 害されていた. 後尖が付着する弁輪が左房拡大によって左房後壁方向に偏位する一方で, 後尖の先端は腱索に よって左室後壁方向に牽引されるので後尖が湾曲するのだと考えた. したがって, 前尖の動きからは Carpetier I型, 後尖の動きからは Carpentirer IIIb型, これらが混合した型の MRだといえる. 一方, AFTRに関しては弁輪 拡大が主因であると報告されており，純粋な Carpentier I型の TRだと考えてよい．まだ十分には確立されていな いものの，AFに続発するこれらの弁逆流の疾患概念と予後, 機序を知っていなければ, 本疾患に出会った際に適 切な治療選択ができない.

(2019年2月12日(火) 08:30 10:30 G会場)

\section{[SY6-2] 心房性機能性僧帽弁逆流例の収縮期弁輪の形態変化}

尾長谷 喜久子，三浦 崇，田倉 雅之，宮永 竜哉，田口 寛子，嶋田 隆志，田崎 雄一，横瀬 昭豪，中路 俊，松丸一朗，江石 清行 (長崎大学)

背景：心房性僧帽弁逆流（MR）の定義は明確ではなく、固有の外科的治療戦略は明らかでない。当科で経験した 心房性 MRについて弁輪、弁尖の収縮期の形態的変化について検討した。方法 : 2016年4月から2018年8月に行 われた僧帽弁形成術140例のうち、心房性 MRを抽出するために1. 左室拡大による機能性 MR症例、2. 明らかな弁 の器質的異常が認められる症例、3. 洞調律の症例、4. 左室駆出率 $<55 \%$ の症例を除外すると7例が残った。これ らの術前3D経食道心エコーデータを用い、解析ソフト（Real View）を用いて、弁輪周囲長、前尖後尖方向（ AP）の径、交連-交連方向（LM）の径、弁輪高、billowing volume（弁輪面より左房側に凸となる弁尖部分の体 積）を計測した。計測は収縮早期の大動脈弁開放直後と収縮後期の大動脈弁閉鎖直前の2つの時相で行い、その変 
化を観察した。結果：収縮早期の弁輪周囲長は129.4 $77.1 \mathrm{~mm}, \mathrm{AP}, \mathrm{LM}$ 径は38.2 $\pm 2.6,42.6 \pm 3.4 \mathrm{~mm}$ あった。計測結果を図にそれぞれ左に収縮早期、右に収縮後期として示している。図より症例3.6の弁輪は左房 によって牽引され経時的に拡大し弁尖は左房側に張り出していることがわかる。これに対し、症例4，5，7では弁 輪は左室の動きに追従し経時的に周囲長、AP. LM径ともに小さくなる。症例 1 では AP径は収縮する一方で、 LM径は拡張、症例 2 はこの逆のパターンを示している。7例の収縮早期の平均交連高は4.6 $1.3 \mathrm{~mm}$ で比較的保た れていた。結語：検討した症例数は少ないが、心房性 MRでは個々の症例で弁輪の動きは異なることが示唆され た。よって、それによって引き起こされる弁尖の変化も多様であると考えられる。心房性 MRの成因にはいくつか の要素が複合的に関連していると思われ、外科的治療に際してはそれらを理解してアプローチする必要がある。

(2019年2月12日(火) 08:30 10:30 G会場)

[SY6-3] Atrial functional mitral regurgitationに対する弁形成術を考察する

梶本 完, 大石 淳実, 遠藤 大介, 李 智榮, 嶋田 晶江, 大山徹真, 上川 祐輝, 畑博明, 桑木 賢次, 山本 平, 天野篤 (順天 堂大学医学部附属順天堂医院心臓血管外科)

近年注目を集めている atrial functional mitral regurgitation（MR）は慢性心房細動に由来する僧帽弁閉鎖不全症 の概念であり、その診断やメカニズムも明らかにされつつある。しかしこの病態への最適な外科治療に関する議 論は始まったばかりでありエヴィデンスの集積が急がれる。2014年1月から2018年8月まで当院で行った初回僧 帽弁手術症例から1）術前心電図が慢性心房細動、2）術前超音波検査所見にて左房径42mm以上かつ左室駆出率 50\%以上、3）弁尖の逸脱や変性がない症例、を抽出し手術方法と成績を後ろ向きに検討した。平均年齢 69歳、男性38例（53\%）を含む72例について検討した。術前 MRの重症度は重症55例、中等度18例で あった。弁置換術は12例、術後再手術、死亡ともに認めなかった。弁形成術は60例、すべてに人工弁輪を使用し た弁輪形成術を実施。そのうち52例（87\%）は rigid ringを使用、人工弁輪サイズの最頻值は28mmであった。そ れ以外の追加手技を表に示す。二次腱索切除34例（56\%）、人工腱索14例（23\%）、弁尖切除や縫合などの処置 19例（32\%）、乳頭筋処置3例（5\%）、弁尖拡張2例（3\%）に行われた。術後死亡は1例（1.6\%）、感染による 逆流再発に対する再手術1例（1.6\%）があり同一症例であった。術後の超音波検査所見では56例（93\%）で僧帽 弁逆流が軽度以下まで消失していた。Atrial functional MRに対する我々の弁形成の治療成績は良好であった が、治療戦略として二次腱索切除を多用している結果であった。本来は secondary MRによる tetheringの解消を 目的とした手技であるが、簡便であり有害事象もなくこうした病態に対しても有効な治療であると考えられ た。手技の方法および病態のメカニズムからその有効性を提示する。

(2019年2月12日(火) 08:30 10:30 G会場)

\title{
[SY6-4] Atriogenic MRの病態の理解と外科治療成績
}

\author{
柴田 利彦 (大阪市立大学 心臓血管外科)
}

弁膜症ガイドライン（2012年）をみると、僧帽弁逆流の発生原因に慢性心房細動は列挙されていない。10年以上 AFが続くと左房拡大が生じ、僧帽弁輪の拡大が続発する症例がある。そのため弁の接合が浅くなり僧帽弁逆流が 発生する。慢性心房細動症例のごく一部がこのような病態(atriogenic MR)となることが、最近になって認識され てきた。

僧帽弁輪は左室に帰属するものと考えられてきたが、 atriogenic MR症例では左室拡大が軽度にもかかわらず僧 帽弁輪が拡大していることから、僧帽弁輪は左室より左房に依存していると推測される。重度 ARによる左室拡 大が僧帽弁輪拡大を起こさないことからも、この推測は裏付けられる。

Atriogenic MRは弁尖の異常ではなくいわゆる機能性逆流である。心不全時には逆流は増加し、安静・利尿によ り逆流は減少するため手術時期を決めるタイミングが遅れ、かなりひどくなってから外科に紹介されることもあ 
る。

この病態は弁輪拡大と後尖の tethering(hamstringing)によるものである。手術としては rigid ringによる僧帽弁 縫縮が基本手術手技であるが、これのみで対処できない症例がある。巨大左房になると弁輪拡大は著明とな り、前尖と後尖との間に間隙が生じる。このような末期的症例では、多くの場合は弁輪は著明に拡大してお り、後尖が小さい症例が多いため弁接合面を確保するために後尖パッチ拡大を要する。高齢者が多いことからリ スクの高い症例では生体弁置換も選択枝である。我々は過去8年に atriogenic MR症例39例の手術を行ってきた が、そのうち10例で後尖パッチ拡大を要した。巨大左房で f波のないためMAZEの適応にならない症例が多い。ま た、有意な三尖弁逆流を有するため全症例でTAPを行った。

これらの術後中期成績をみると MRが著明に減り心不全再入院が減少するが、術前に重度 $T R$ を有する症例およ び左房容積が $130 \mathrm{ml} / \mathrm{m} 2$ 以上の症例で、術後 MACE発生が有意に高かった。

このようなことから左房容積拡大や重度 T R になる前に、外科的介入をすべきだと考える。また、最近では積 極的に左房縫縮手技を追加している。

(2019年2月12日(火) 08:30 10:30 G会場)

\section{[SY6-5] 慢性心房細動合併僧帽弁閉鎖不全症に対する僧帽弁形成術の検}

\section{討：術前左房径の影響}

○齋藤 博之, 新浪 博士, 齋藤 聡, 西中 知博, 新川 武史, 菊地千鶴男, 松村 剛毅, 道本智, 東 隆, 澤 真太郎, 日野 阿斗 務，入江翔一，中前 亨介，阿瀬 孝治，池原 大烈 (東京女子医科大学)

【目的】慢性心房細動を合併した僧帽弁閉鎖不全症に対する僧帽弁形成術の成績を検討する。特に術前の左房径 が術後遠隔期の洞調律維持率、及び左心機能に及ぼす影響について検討した。【対象と方法】2006年7月から 2018年6月までの12年間に当科にて施行した52例の慢性心房細動（af）を合併した僧帽弁閉鎖不全症（MR）手 術症例のうち遠隔期に経胸壁心エコー（TTE）評価が可能であった41例を対象とした。術前 TTE上の左房径（ LAD）により2群に分類した。I群 LAD $<52 \mathrm{~mm} \mathrm{~N}=18$ ， II群 LAD $>53 \mathrm{~mm} \mathrm{~N}=23$ であった。術後駆出率（ $E F ） 、$ 洞調律維持率および左室拡張末期径（LVDd）を比較検討した。【結果】観察期間中央値は1281.4日、男 26例（63.4\%）、手術時平均年齢66.5歳であった。病変は prolapse 22, chordal rupture 9, tethering 9, perforation 1であった。17例 (41.3\%) に前尖病変を認めた。両群間の術前因子の比較検討では 年齡、MR grade、病変位置、LVDd $(\mathrm{mm})$ ，EF（\%)に両群間に有意差は認めなかった。手術は人工弁輪 Physio II ring 32， Tailor Flexible Ring 3, Physio ring 3, CG future 2, Tailor Flexible Band 1をそれぞれ使用した。使用人工弁輪サ イズは平均29.2 mmであった。31例（78\%）にMaze手術、29例（70.7\%）に三尖弁輪形成術を併施した。人工 腱索による腱索再建術を5例に施行した。2例で弁形成困難のため弁置換術に術式変更した。術式等に両群間に有 意差は認めなかった。遠隔死亡、再手術を認めなかった。遠隔期の TTE検査で MRは38例（92.7\%）で mild以下 であった。遠隔期洞調律維持率は全体で43.9\%であり|群は $72.2 \%$ あ゙ったのに対し I群では21.7\%だった（ $\mathrm{P}<0.05)$ 。術直後は LVDdは I群47.4 mm，II群51.5 mmへ両群とも有意に術前と比較して改善（ $\mathrm{P}<0.05 ） し$

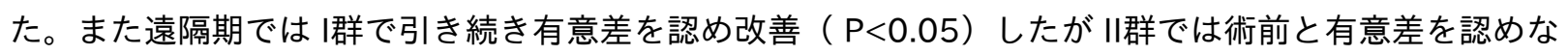
かった。【考察】1. 慢性心房細動を合併した僧帽弁閉鎖不全症に対する僧帽弁形成術とMaze手術の成績は良好で あった。2. 術前左房径が52 mm以下の症例では積極的に Maze手術を施行する事が推奨され、遠隔期の高い洞調 律維持による抗凝固療法離脱及び左室機能の回復が期待できる。3. 遠隔期の洞調律と左室機能維持のためには左 房拡大に至る前の手術介入が適当である。

\section{[SY6-6] 拡張型心筋症に合併しない後尖 tetheringを伴う前尖逸脱 MRに対 する外科治療の検討}


○田中 千陽, 鎌田 啓輔，小市 裕太，若林 尚弘，伊勢 隼人，中西 仙太郎，石川成津矢，紙谷 寛之 (旭川医科大学)

目的 : 近年、前尖の pseudo-prolapse(PP)や atrial mitral regurgitation (AMR)など拡張型心筋症に合併しない後 尖 tethering関連の僧帽弁逆流(MR)が注目されている。前尖逸脱症例において後尖の tetheringの指標として左室 収縮中期の閉鎖角を測定し、術式、術前後の心エコー所見を比較検討した。また弁輪異常運動を呈する atrial disjunction(AD)症例についても検討した。方法 : 当施設で2015年1月から2018年7月までに、3度以上の重症 MRに対し手術を施行した122例のうち、MVR施行例、活動性 IE、重症 AR併存、虚血性/非虚血性心筋症に合併 したMRを除外した66例を対象とした。後尖逸脱例を除外し、PPを含む前尖冕脱が原因の MRを抽出し、後尖の 閉鎖角により2群に分類し、それぞれでの手術術式、術前後の心エコー所見を後ろ向きに比較検討した。結果 : 対

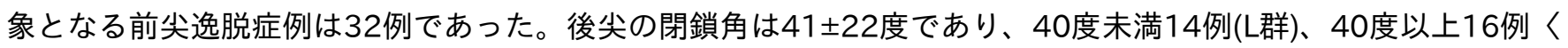
$\mathrm{H}$ 群〉であった。L群は H群と比べ平均肺動脈圧が低かったが $(L$ 群 $17 \pm 6 \mathrm{mmHg} 、 \mathrm{H}$ 群 $25 \pm 8 \mathrm{mmHg} 、 \mathrm{P}=0.02)$ 、 EF、SVI、僧帽弁弁輪径、逆流量には差はなかった。術式は L 群で弁輪形成のみ2例、弁形成施行12例で、H群は 弁輪形成のみ7例、弁形成施行9例で、H群で弁輪形成のみ施行した症例が多い傾向であった。L群では弁輪形成 例は弁形成例より Dd、Dsが小さく（Dd;45 $\pm 4 \mathrm{~mm}$ vs $57 \pm 11 \mathrm{~mm} 、 \mathrm{P}=0.04 、 \mathrm{Ds} ; 27 \pm 0 \mathrm{~mm}$ vs $29 \pm 12 \mathrm{~mm}$ 、 $\mathrm{P}=0.03) 、 \mathrm{H}$ 群では弁輪形成のみ施行例では弁形成例より $\mathrm{EF}$ が低く( $51 \pm 13 \%$ vs $66 \pm 12 \% 、 \mathrm{P}=0.02) 、 \mathrm{Ds}$ 㚐大 きく $(45 \pm 9 \mathrm{~mm}$ vs $33 \pm 8 \mathrm{~mm} 、 \mathrm{P}=0.02) 、 \mathrm{SVI}$ が大きく $(39.0 \pm 13.1 \%$ vs $25.1 \pm 6.8 \% 、 \mathrm{P}=0.03) 、 \mathrm{~A} 2$ 病変が多 かった $(100 \%$ vs 44\%、P=0.02)。また ADを呈したものは4例あり、後尖の閉鎖角は58 20 度で20度以外の3例 (70 \pm 10 度)で弁輪形成のみを行った。術後の MRはL 群0.3 $\pm 0.4 、 H$ 群0.2 \pm 0.3 、術式別で弁輪形成例 $0.1 \pm 0.1$ 、弁 形成例 $0.3 \pm 0.4$ で有意差なかった。観察期間は平均585 5382 日で、L 群と H群、弁輪形成例と弁形成例で再手術 率に差がなかった（ $P=0.57 ） 。$ 結論 : 前尖冕脱による MR症例では、PP、AMR、ADを含め後尖閉鎖角が40度 を超える例では肺高血圧になりやすいが、形体的には弁輪形成術のみで MR制御可能な例が多く、後尖の極端な低 形成以外では augmentationなどの追加処置は不要と考える。

(2019年2月12日(火) 08:30 10:30 G会場)

[SY6-7] 心房細動症候群に対する包括的外科治療の重要性

○山口 裕己 (昭和大学江東豊洲病院＼cjkstart循環器センター 心蔵血管外科)

(2019年2月12日(火) 08:30 10:30 G会場)

[SY6-8] Atrial functional MRに対する僧帽弁輪縫縮術の治療成績

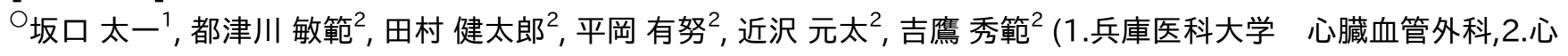
臓病センター榊原病院)

OBJECTIVES: Surgical ring annuloplasty is generally performed in patients with symptomatic atrial functional mitral regurgitation (MR) caused by long-standing atrial fibrillation (AF). However, its clinical results have not been well reported. METHODS: Twenty-four consecutive patients with atrial functional MR (mean age of $71 \pm$ 10 years) underwent mitral annuloplasty. Concomitant procedures included AF ablation in 17, tricuspid annulplasty in 19, and coronary artery bypass grafting in 3 patients. The median ring size was $28 \mathrm{~mm}$. RESULTS: There were no hospital mortalities. At discharge, the mean left atrial (LA) volume index had decreased from $89 \pm 55 \mathrm{ml} / \mathrm{m} 2$ to $57 \pm 30 \mathrm{ml} / \mathrm{m} 2(P=0.0014)$, while the left ventricular (LV) dimensions and ejection fraction did not change significantly. The mean tricuspid regurgitation peak gradient had also decreased from $34 \pm 12 \mathrm{mmHg}$ to $23 \pm 5 \mathrm{mmHg}(P$ 


\section{[SY6-9] 当院における atrial functional MRに対する手術治療と術後心機能 の推移}

○川本 尚紀, 福嶌五月, 島原 佑介, 山崎 琢磨, 松本 順彦, 山下 築, 小林 順二郎, 藤田 知之 (国立循環器病研究セン 夕ー)

背景 ; 長期間に及ぶ心房細動の結果、左室機能や弁 ·弁下組織に異常が認められないにも関わらず機能性の僧帽 弁閉鎖不全症(atrial functional MR)が起こることは知られているが、その手術治療、術後経過に関する報告はほと んどなく、今回、当院における atrial functional MRに対する手術成績を発表する。方法 ; 2002年以降、当院で施 行された atrial functional MRに対する僧帽弁手術31例（平均年齢71土8歳、男性21例）を対象とした。心房細動 罹患期間は15 10 年。Moderate以下の MRは10例（32\%）に認めた。術前の左室拡張末期径は(LVDd)59 8 $\mathrm{mm}$ で LVDd 55mm以上拡大症例は22例(71\%)に認めた。左房径(LAD)は64 $13 \mathrm{~mm}$ となった。また、左室駆出 率(EF)は58 8 \% であり、EF55\%以下の心機能低下例は13例(42\%)に認められた。術前 3 度以上の TRは 15 例 (48\%)に認められた。フォローアップ期間は3.9 3.6年であった。結果 ; 僧帽弁手術31例中、 ring annuloplastyによる僧帽弁形成術(MAP)は26例(84\%)、僧帽弁置換術(MVR)は5例(16\%)であった。MAPにおける

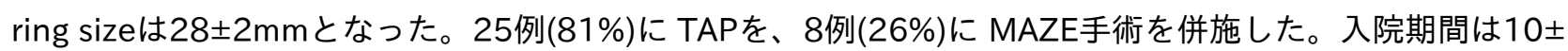
3日、手術死亡は0例であった。術後の LVDdは54 $\pm 7 \mathrm{~mm}, L A D は 55 \pm 10 \mathrm{~mm}, E F は 51 \pm 11 \%$ と術前と比較して有意

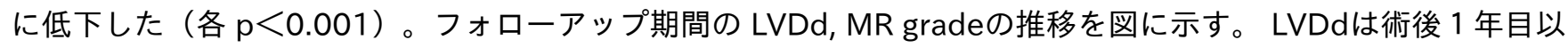
降は変化ないが、MR gradeは有意に上昇することがわかった $(0.23 /$ year, $\mathrm{p}<0.001)$ 。フォローアップ期間中に 2度以上の MRに進行した症例は 9 例認め、2度以上の MR再発4年回避率は51\%であった。術後フォローアップ期 間に2度以上の MRに進行する因子を探索すると、LVDdが55mm以上に拡大している症例で多くなる傾向と なった( $\mathrm{p}=0.25, \mathrm{HR}$ 3.01，Cl 0.5-58.2)。結語 ; 左室拡大の認められる atrial functional MRに対する ring annuloplastyでは、術後中長期に MRが進行する可能性がある。

(2019年2月12日(火) 08:30 10:30 G会場)

\section{[SY6-10] 再発因子から再考する AtriogenicMRに対する手術方針}

古市 吉真，小宮 達彦，島本 健，野中 道仁，松尾 武彦，北浦順也 (倉敷中央病院)

はじめに：僧帽弁閉鎖不全症(以下 MR)に対する僧帽弁形成術(以下 MVP)の成績は非常に良好となり、一定の成績 となりつつある。しかし、心房細動による左房拡大主体の Atrial MRに対しては逆流の再発がしばしば認めら れ、形態によっては僧帽弁置換術を施行すべき症例がある。今回当院における Atriogenic MRの成績を報告し、僧 帽弁輪縫縮術(以下 MAP)後の再発因子を同定する。対象と方法 : 対象と方法 : 2008年から2017年に施行した、 MRに対するMVP608症例の内、弁尖に対する形成術を行わず、MAPのみ施行した、心房細動による左房拡大主 体の Atrial MR 54例を対象とした。遠隔期に術後 MR $2^{\circ}$ 以上の再発がなかった44例と再発を来した 10 例に関して 術前の経胸壁エコー(以下 TTE)、経食道エコー(TEE)の dataを比較し、再発因子に関して検討した。心不全再入 院、全死亡に関しても評価した。結果 : 再発群では有意に年齢が高齢(71.0 07.5 歳 vs 75.2 \pm 3.9 歳、 $p=0.018)$ で あり、女性の割合が多い傾向にあった $(52 \%$ vs $20 \% 、 p=0.052)$ 。また術前の腎機能が有意に不良であった(eGFR 62.2 vs 45.2、 $p=0.023) 。$ どちらの群も術前 chronicAfが9割、pafが1割であった。BSAや術前の脳梗塞既 往、心不全入院歴、Af罹患歴、NYHA、BNPに関しては有意差を認めなかった。平均フォローアップ期間は

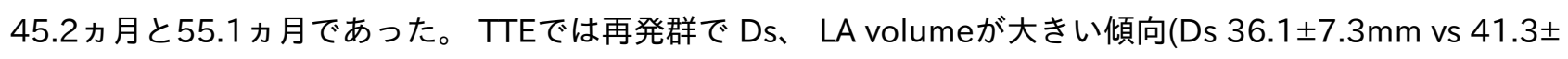
$9.1 \mathrm{~mm} 、 p=0.058$ Lavolume $202.6 \pm 120.5 \mathrm{ml}$ vs $291.1 \pm 160.5 \mathrm{ml} 、 p=0.072) 、 T^{\circ} 2^{\circ}$ 以上の割合が高い傾向

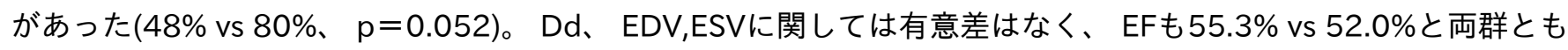
に数值上の心機能は保たれていた。手術に使用した弁輪のサイズは平均 $29.7 \mathrm{~mm}$ vs $29.9 \mathrm{~mm}$ で差はなく、 Maze併施は非再発群52\%、再発群30\%で有意差はなかった。TEEでは前後径(AP)、横径(CC)、前尖の長さ (A2)、後尖の長さ $(\mathrm{P} 2)$ 、前尖角度、後尖角度、大動脈僧帽弁角度、Tenting heightを評価したが、有意差を認めた ものはP2のみであった。 $(p=0.036)$ Cox-Hazard modelによる多変量解析では逆流再発因子は Ds(HR 1.126、 
$\mathrm{p}=0.020)$ と P2(HR 0.762、 $\mathrm{p}=0.022$ )が抽出された。後尖の長さに関する ROC曲線では cut offが9.9mmと算出 された。結語：Atriogenic MRは後尖が10mmない症例は MVRを施行すべきである。 
シンポジウム|共通

\section{シンポジウム 07}

\section{心臓血管外科における周術期感染対策の現状と将来(日本外科感染症学会合 同企画）}

座長:田中 啓之(久留米大学),井本 浩(鹿児島大学)

2019年2月13日(水) 08:00 09:50 B会場 (岡山コンベンションセンター $2 F$ レセプションホール)

(2019年2月13日(水) 08:00 09:50 B会場)

[基調講演] 周術期感染の新しい対策

○草地 信也 (東邦大学医療センター大橋病院＼cjkstart外科)

(2019年2月13日(水) 08:00 09:50 B会場)

[SY7-1] 心臓血管外科手術における手術部位感染予防 -術中投与のみの予防 的抗菌薬適正使用-

○宮原 健, 松浦 昭雄, 竹村 春起, 齋藤 俊英, 大塚 良平, 山本 暁邦 (一宮市立市民病院 心臓血管外科)

【背景】手術部位感染(SSI)に関しては、近年 WHO(2016)、ACS(2016)、CDC(2017)の3つの予防ガイドライン が発出されたが、推奨内容には一部相違がみられる。予防的抗菌薬に関しては、CDCは術中のみで手術室で閉創 後は追加投与しないとし、他は心臓血管外科では48時間以内も容認している。わが国の術後感染予防抗菌薬適正 使用のための実践ガイドラインにおいても術後48時間までの投与が推奨されている。WHOは2015年に「薬剤耐 性に関する国際行動計画」を採択し、2016年、わが国は「薬剤耐性アクションプラン」を決定した。2020年ま でに静注抗菌薬使用量を2013年の水準から 20\%削減することが目標の 1 つである。抗菌薬の適正使用は喫緊の国 際的問題である。【目的】当院では早期から予防的抗菌薬は術中投与のみで行ってきた。その妥当性を検証す

る。【対象と方法】2003年1月から2018年8月までの胸骨正中切開による連続2282例を対象とした。抗菌薬はセ ファゾリン $1 \mathrm{~g}$ を麻酔導入直後から4時間毎に追加し術中のみで終了とした。鼻腔内 MRSA保菌者に対してはバンコ マイシン0.5gを併用した。期間中に以下の感染防止策を追加した。術野消毒は $0.5 \%$ クルヘキシジン・アル コールを擦り込み後 $10 \%$ ポビドンョードを塗布。手術時手洗いは仕上げに $0.2 \%$ ロルヘキシジン・アルコールを 擦り込み。スタッフ全員が二重手袋を着用し outerを頻回に交換。ステロイドユーザーおよび低体温手術例を除き 術中のステロイドは投与せず。術中から血糖值を $140 \mathrm{mg} / \mathrm{dL}$ 以下を目標に管理。胸骨ワイヤーを6本に増加。閉創 時に温生食のみによる創洗浄を施行。術後2時間にわたり80\%以上の高濃度酸素を投与。包交は, 第2病日に1回 のみ。その際, 被覆剤としてハイドロコロイド・ドレッシング材を第7病日まで貼付。2007年3月以降はこれらす べての防止策をバンドルとして全例に例外なく施行した。なお抗菌薬の局所使用は行わず抗菌縫合糸も使用して いない。【結果】deep SSI（DSWI：深部胸骨感染症）は27例(1.2\%)に発生した。バンドル導入後は1354例中 5例のみ(0.4\%)で有意に減少した $(P<0.0001)$ 【結論】 DSWIは満足すべき低值に抑えられており，現行の当院の 感染防止策は適切と思われる。感染防止策にはガイドラインによっては推奨されないものも含まれるが、有害性 はなく費用も見合う。これらをこだわりを持って完全に実施すれば、心臓血管外科手術においても予防的抗菌薬 は術中投与のみで良い。

(2019年2月13日(水) 08:00 09:50 B会場)

\section{[SY7-2] SSIに対する当院の取り組み（多職種で考え、実行する）}

鈴木 龍介, 平山 亮, 坂口 健, 上木原 健太, 浦下 周一, 吉岡 祐希, 宮本 智也, 小島 丈典, 松川舞 (熊本赤十字病院 心 臓血管外科) 
【はじめに】心臓血管外科術後縦隔炎は発生させたくない合併症のひとつであり, 様々な対策が報告されている がマニュアルとしてひとつにまとめてあるものは少ない. 我々は院内の各部署と連携して当院独自の術後創部感 染症対策のマニュアルを作成してきた．毎年改訂を続け今回2015年版を発表した．その取り組みを通じて縦隔炎 を減らすことが可能であったかを検討した.【対象と方法】2009年1月から2016年12月までに当科で施行した 1368例を対象に前期を2009年1月から2012年12月までの655例と, 後期を2013年1月から2016年12月までの 713例に分けて検討した.【結果】年齢は前期／後期で平均69.4歳／69.1歳, 手術時間がそれぞれ286分と 298分，JANISによるリスクスコアは1.37と1.37と同等であったJANISの分類に従い,前期後期の症例数は CARDが494例, CBGBが483例, CBGCが28例. 胸部大動脈の手術をTAAとし363例であった. SSI発生率は前 期 $4.1 \%$, 後期3.9\%(P=0.89) と有意差はなかった.縦隔炎はそれぞれ $1.68 \%$ から0.7\% $(\mathrm{P}=0.13)$ に低下しており, 有 意差はないものの効果を認めた.【まとめ】マニュアルは作成するだけでは効果がなく, それを確実に実行に移 し，さらにその結果を検討するPDCAサイクルを回すことが必要と考える．完全にSSIをゼロにはできていない が，マニュアル作りを通して院内の意識が変化したことで縦隔炎の発生を抑制できたと考える.引き続きマ ニュアルの改訂を行い当院の状況を加味したオリジナルのマニュアルを作っていきたい. マニュアル作りを通じ て当院で行っているSSIを減らすための取り組みを紹介する.

(2019年2月13日(水) 08:00 09:50 B会場)

\section{[SY7-3] 心臓手術における感染予防抗菌薬使用一適正使用のための実践ガイ ドライン作成と心臓血管外科施設へのアンケート調査一}

○柚木 靖弘, 桑田 憲明, 田淵 篤, 田村 太志, 渡部 芳子, 本田 威, 山澤 隆彦, 古川博史, 金岡 祐司, 種本 和雄 (川崎医科 大学心臓血管外科)

心臓血管外科領域の手術は原則として清潔手術であり surgical site infection (SSI)が発生することはまれである. しかし，SSIは重篤な合併症となりうるため適切 な予防対策が大切である．この度，日本外科感染症学会と合同で作成した「術後感染 予防抗菌薬適正使用のための実践ガイドライン」に日本化学療法学会の委員として参 加した.

ガイドラインでは冠動脈バイパス手術・心臓弁膜症手術には CEZを推奨し, 皮膚切開 1 時間前以内に投与を開始することとした. 3 時間超の手術や大量出血時には追加投 与を行う. 術後は48時間の投与を推奨した. 術前MRSA保菌者に対しては. 術前の Mupirocinによる除菌と予防的抗菌薬として CEZと VCMの併用を推奨した.

日本心臓血管外科学会の協力を得, 本邦の代表的心臓血管外科施設にアンケート調査 を行った. 第一選択抗菌薬は CEZが80\%, ABPC/SBTが12\%であった. 術後投与期間は施 設間に差がみられた. 術後に追加抗菌薬投与を行わない施設が 3\%見られた一方で, 術後7日間投与をするとした施設も $7 \%$ あった. 最頻值は術後2日間で，50\%であっ た.

2016年末にWHOが「術後の予防抗菌薬投与は不要」と推奨し, さらに2017年には CDCか らも同様の勧告がなされた.しかし，心臓・胸部大動脈領域ではこの点は未だ controversialと思われる. 耐性菌の誘導を抑えつつ, SSIの発生も低率にする必要が あり, 今後とも適正な抗菌剤使用に努めていきたい. 
○河村 愛, 戸田 宏一, 宮川 繁, 吉川 泰司, 秦 広樹, 吉岡 大輔, 甲斐沼 尚, 河村 拓史, 吉田 昇平, 上野 高義, 倉谷 徹, 澤 芳樹 (大阪大学)

【背景・目的】胸骨正中切開後の縦隔炎は開心術における重大な合併症の 1 つである。リスクファクターや診 断・治療法について、これまで様々な報告がなされてきたが、未だ統一された見解はない。我々の施設では発熱 等の臨床所見、CT等の画像所見およびドレーン・ペースメーカーワイヤー抜去後の培養検査を基に、縦隔炎が疑 われる症例については、大網充填やVacuum Assisted Closure (VAC) を用いた外科的治療を積極的に行ってき た。今回、外科治療を要した縦隔炎症例を retrospectiveに検証し、リスクファクターの解析を行うとともに、早 期診断のためのドレーン・ペースメーカーワイヤー培養検査の有用性について調査したので報告する。

【対象・方法】2002年 1 月 2017年12月に施行した胸骨正中切開アプローチによる開心術（小児・VAD植え込 み術・心臓移植を除く）のうち、データベースを用いて検討が可能であった3393例を対象とした。このうち外科 的治療を要した縦隔炎は65例 (1.92\%) であった。縦隔炎群と非縦隔炎群の患者背景を比較し、単変量・多変量 解析を用いてリスクファクターの解析を行った。またドレーン・ペースメーカーワイヤーの培養結果より、感 度・特異度等を調査した。

【結果】単変量解析の結果、術前因子では慢性透析、開心術既往、心原性ショックが、また術中因子では大動脈 手術、手術時間、体外循環時間、大動脈遮断時間が、術後因子では輸血、術後透析、術後再開胸止血術が縦隔炎 のリスクファクターとして挙げられた。これらを用いて多変量解析を行ったところ、術前慢性透析患者、大動脈 手術、手術時間、術後透析で有意差を認めた。ドレーン・ペースメーカーワイヤーの培養結果は感度 $50.0 \%$ 、特 異度 $90.9 \%$ 、陽性的中率 $10.6 \%$ 、陰性的中率 $98.9 \%$ でった。陽性的中率は菌種によって異なる值を示した。 【結語】今回の検討では、開心術後の縦隔炎の発症には、術前・術後の透析、大動脈手術、手術時間がリスク ファクターとなることが示唆された。ドレーン・ペースメーカーワイヤー培養は高い特異度・陰性的中率を示 し、特に縦隔炎の否定に有用であると考えられた。

(2019年2月13日(水) 08:00 09:50 B会場)

\section{[SY7-5] 術後縦隔洞炎の根絶を目指して：周術期を通した多職種による多角 的アプローチ}

○高木 数実, 有永 康一，飛永 覚, 佐藤 晃, 高瀬谷 徹, 庄嶋 賢弘, 新谷 悠介, 財満 康之, 税所 宏幸, 福田 倫史, 押領司 篤 宣, 田中 啓之 (久留米大学医学部外科学講座)

背景：縦隔洞炎は、高い死亡率、入院コスト増大や QOL低下など引き起こす重篤な合併症である。これまで当科 では、術後持続インスリン静注 $(C V I I)$ 、予防的抗生剂見直し、GM+CEZ術野散布などを段階的に導入したが、弁 膜症手術での発生率が増加していた。現在、当科で行っている対策について報告する。方法 : 2008年から 2017年に施行した開心術：2447例の縱隔洞炎発生率と危険因子(年齢、DM、CKD、COPD、緊急手術、長期人 工呼吸器)の推移を、前期と後期、手術手技(冠動脈：C、弁膜症：V、大動脈：A)に分け検討し、その対策を 行った。結果：縦隔洞炎は28例(1.1\%)に認め、起炎菌は93\%(26例)で MRSAであった。年次推移では、C群の発 生率は一定で、A群は経年的に減少したが、V群で増加した(図1)。危険因子(前期 vs 後期)は、年齢(V群 : 68.3歳 vs 70.8 歳)、CKD(C群 : $15 \%$ vs $37 \%$ 、V群 : $9 \%$ vs $34 \%$ 、A群 : $12 \%$ vs $23 \%$ )、COPD(V群 : $17 \%$ vs $27 \%$ 、 A群 : 9\% vs 24\%)に有意差 $(p<0.001)$ を認め、2017年の縦隔洞炎4例は、75-86歳、CKD、COPD合併とこの傾 向を反映していた。高齢化とそれに伴う危険因子の増加が主因と考え、医師(外科、内科、麻酔科、感染制御)、看 護師(外来、手術室、病棟)、薬剂師による多角的アプローチとして、【外来】高齢者の入浴指導、鼻腔 MRSAスク リーニング、インスリン強化療法と栄養指導、【術前】剃毛範囲限定、術前日入浴指導、【術中】予防的抗生剤 (CEZ+VCM)の適切な投与法遵守(量と時期)、ハイリスク症例でのオラネジン消毒、アルゴンレーザーによる胸骨 止血、抗生剂術野散布、2 重手袋着用、【術後】CVII、48時間の抗生剂(CEZ)投与、【その他】処置時のスタン ダードプリコーション実施、パームテストによる定期的手洗い確認、を本年4月より導入し、以後の連続127例で 縱隔洞炎は認めていない。結語：高齢化、重篤化する開心術における縦隔洞炎対策には、周術期を通した多職種 による多角的なアプローチが必要である。 
(2019年2月13日(水) 08:00 09:50 B会場)

\section{[SY7-6] 前縦隔炎・創部感染 outbreakの経験}

${ }^{\circ}$ 廣瀬 圭一 ${ }^{1}$ ，猪飼 秋夫 ${ }^{1}$ ，長門 久雄 ${ }^{1}$ ，村田 眞哉 ${ }^{1}$ ，菅野 勝義 ${ }^{1}$ ，今井 健太 ${ }^{1}$ ，石道 基典 ${ }^{1}$ ，太田 恵介 ${ }^{1}$ ，荘司 貴代 ${ }^{2}$ ，光延 智 美 $^{3}$, 坂本 喜三郎 ${ }^{1}$ (1. 静岡県立こども病院 心臓血管外科, 2.静岡県立こども病院 小児科, 3.静岡県立こども病院 感染対策室)

【背景】術後の前縦隔炎は予後のみならず、長期入院など患者・家族と医療従事者双方に物理的・精神的に負担 を強いることになる。当科では昨年秋、前縦隔炎・創部感染の outbreakがあり対策を強いられた。【対 象】2017年10ー12月に手術を行った55名。男女比は32:23。平均年齢3.4歳（3日-30歳、中央値1.5歳）。主な 術式はVSD閉鎖8、BDG7、TCPC6、RVOTR5、PAB4他。この間に発症し、感染症サーヴェイランスに基づい て診断した前縦隔炎は9例（現手術室稼働2007年4月 2017年9月の前縦隔炎32例/全3460例）、創部感染は5例 と outbreakした(ただし、a.気管形成と同時手術で気管吻合部破綻 b.膿胸がある中で準緊急・開胸手術、の2例の 前縦隔炎は因果関係がはっきりしておりカウントはしたが検討対象外とした)。前縦隔炎の内容は（以下年齢、原 疾患、手術、術後発症日、起因菌）A.1歳10か月、VSDの女児。根治術後29日目、MSSA。B.3か月、HLHSの 女児。Norwood術後58日目、MRSA。C.7歳、左室型単心室の男児。TCPC後7日目、MRSA。D.総動脈幹症の 2歳の男児。RVOTR後8日目、S.Lugdunensis。E.PAVSDの1か月の女児。mBT後29日目、MSSA。F.AVSDの 1か月の女児。PAB後24日目、MSSA。G.VSDの8カ月の女児。根治術後15日目、MRSA。前縦隔炎が3例発症し た段階で院内調査開始、4例発症後手術を中止（ただし、緊急手術を除く）、さらに外部委員による調査も行われ た。患者背景には共通した因子がなく、いくつかの原因が考えられ、対策をとった。主な原因・対策は A. 手術室 原因 a.室内空気からブドウ球菌を含む雑菌が検出された（平成21年より清掃業者が変わり頭上の清掃を行って いなかった） b.長年置きっぱなしになっている装置が多い＼cjkstart対策 a.清掃・消毒の見直し b.ダクト位置も考慮した 手術室内の物品移動、など。B.手術 対策 a. 手袋は二重、3時間ごとに交換 b.胸骨の止血は焼灼しすぎない c. 洗 浄は洗浄水が跳ねないよう注意する d. 縫合方法・糸の見直し、など。【結果】発症患者は全例退院、感染の再発 なし。対策を立て委員会の承認を経た後手術を再開、以降前縦隔炎の発症をみていない（他院転院後発症

1）。【結語】突然の前縦隔炎·創部感染の outbreakから院内・外部委員の調査も含めた感染対策を行い、再発 をみていない。特に約10年の頭上の清掃不良による雑菌落下は注意すべきポイントと考えられた。貴重な経験を 得たと考え、検証・報告する。

(2019年2月13日(水) 08:00 09:50 B会場)

\section{[SY7-7] 小児心臓外科領域における新たな周術期感染対策}

松原 宗明, 園部 藍子，山本 隆平，石井 知子，中嶋 智美，加藤 秀之，上西 祐一朗，大坂 基男，坂本裕昭，平松 祐司 (筑 波大学 心臓血管外科)

【目的】昨今の”早期治療と予防”による感染医療対策により心臓外科清潔手術(Classl)後の感染症発生率は飛躍 的に減少した。しかしながらインプラント留置の多い小児心臓術後では、ひとたび重症(特に MRSA)感染が生じる と抗菌薬耐性のみならずバイオフィルム形成により容易に難治化し、時にインプラント除去を余儀なくされ る。当院では時代変遷に準じた周術期感染予防対策や生じてしまった術後 MRSA感染症に対する新たな治療法を 行ってきたが、その成績や問題点を後方視的に検討した。【方法】2014年以降に小児開心術を行った連続214例 を対象とした。MRSA保菌者に対するムピロシンによる術前鼻腔粘膜除菌や抗 MRSA薬による術前単回予防投 与 ·術前皮膚消毒薬の変更等、周術期管理を修正した2015年からの症例を A 群(151例)、A群以前の症例を B 群 (63例)とした。術後に縦隔炎を生じた症例は直ちに創部のドレナージを行い局所閉鎖陰圧療法に移行。次いで『早 期に効果的に低侵襲で鎮静化する』というコンセプトのもと抗生剤は臟器及び組織移行性に準じた2剂(抗 MRSA静注薬+RFP)を早期より使用し、その後に数ヶ月間経口薬3剂(ST+RFP+CLDM等)の内服を行うバイオ 
フィルム形成阻害を目的とした多剤薬物療法を行った。【結果】術後縦隔炎発症例は A群3例(1.9\%)、B群4例 (6.3\%)(P<0.05)。なお術前 MRSA保菌者（オッズ比1.74、95\%信頼区間1.12-2.72）のみが有意な周術期危険 因子であった。術後縦隔炎を生じた全7例の手術時年齢中央值1.6歳 (2ヶ月〜7歳)、体重中央值8.1 kg (3.0 17.8)。4例で開心術時にインプラント留置が行われ5例で複数回の開心術の既往があった。抗生剂加療終了 後の平均542 (212 912)日の観察期間内に感染再燃例はなく長期薬物内服に伴う副作用出現も全例認めていな い。【結論】小児心臓術後にしばしば問題となる MRSA感染を主とした当院の周術期感染対策は術後感染症発症 率軽減に効能を示したが未だゼロには抑制できていない。しかしながら、たとえ術後難治性感染症を発症したと してもバイオフィルム形成の早期抑制を目的とし Definitive firstに注目した当院の新しい治療対策を行う事で再手 術回避や患者のQOLを向上させる傾向を示しえた。今後 MRSA保菌撲滅を含め、抗菌薬の耐性化防止につながる 更に至適な感染対策法を確立していきたい。 